\title{
Acacia pendula (Weeping Myall) in the Hunter Valley of New South Wales: early explorers' journals, database records and habitat assessments raise doubts over naturally occurring populations
}

\author{
Stephen Bell ${ }^{1,3}$ \& Colin Driscoll ${ }^{2}$ \\ 1 Eastcoast Flora Survey, PO Box 216 Kotara Fair NSW 2289, sajbell@bigpond.com \\ 2 Hunter Eco, PO Box 1047 Toronto NSW 2283, cd_enviro@bigpond.com \\ 3 School of Environmental and Life Sciences, University of Newcastle, Callaghan NSW 2308
}

\begin{abstract}
Acacia pendula, Weeping Myall, (family Fabaceae) is the most legislatively protected plant species in the New South Wales Hunter Valley. Under the NSW Threatened Species Conservation Act 1995 it is listed as an Endangered Population (in the Hunter Valley) and as a component of two Endangered Ecological Communities (one in the Hunter, one elsewhere in NSW); it is also listed as a Critically Endangered Ecological Community (in the Hunter Valley) on the Commonwealth Environment Protection and Biodiversity Conservation Act 1999 and listed as threatened in three other eastern Australian States.
\end{abstract}

To ascertain the likely original distribution of stands of Acacia pendula in the Hunter Valley, this paper examines the writings of early Australian explorers, herbarium and database records, and the species habitat attributes across NSW. None of the journals examined, including those of botanist/explorer Allan Cunningham (who originally collected Acacia pendula from the Lachlan River in 1817), Thomas Mitchell or Ludwig Leichhardt, make note of the species for the Hunter Valley. Several explorers do, however, record Acacia pendula regularly (>100 times) across other parts of NSW, Queensland, and South Australia.

Historical herbarium and database records show a paucity of records from the Hunter prior to the year 2000, after which a 37 -fold increase in observations since 1951 is apparent. For the first 128 years of botanical exploration (1823 to 1951), there are no validated collections or records of Acacia pendula from the Hunter Valley. The single exception is a specimen collected by Cunningham from 1825 (lodged at Kew, UK), purported to be from 'Hunters River', but which is morphologically different to other collections of Acacia pendula from that time. There is some uncertainty over the origins of this specimen.

Analysis of habitats supporting Acacia pendula in NSW outside of the Hunter show them to differ significantly in geological age, soil type, rainfall and elevation from those in the Hunter.

Collectively, these findings provide a strong circumstantial case that Acacia pendula was absent from the Hunter at the time of European settlement; this has important implications for the conservation and management of Hunter stands. Rather than being a threatened species in the Hunter Valley, it is postulated that Acacia pendula has been intentionally and/or accidentally introduced to the region, and may now be imposing a new and emerging threat to the endangered grassy woodlands and forests there. There is now an urgent need for genetic studies to clarify the origins of the current Hunter Valley stands, and to define the taxonomic limits of Acacia pendula and its close relatives.

Cunninghamia 14:(2014) 179-200

doi 10.7751/cunninghamia.2014.14.009 


\section{Introduction}

"I rode up the creek about three quarters of a mile, and came upon those extensive plains before-mentioned ... covered with a great variety of new plants, .... encircled by a new species of Acacia, which received the specific name of pendula, from its resembling in habit the weeping willow".

So wrote explorer John Oxley on May 5th 1817, while in country west of Bathurst in central western New South Wales (Oxley 1820). Acacia pendula A.Cunn Ex G.Don or Weeping Myall as it is now commonly referred to, is a tall, graceful shrub or small tree widespread in the interior regions of eastern Australia. It is indeed characterised by the grey-green, pendulous foliage that is reminiscent of Weeping Willows (Salix babylonica). With Oxley was Allan Cunningham, the King's botanist, and it was he who collected the type of Acacia pendula from the Lachlan River. The formal description of the species was later included in the work of Don (1832), some fifteen years after Cunningham had first encountered it. Despite a long history of revisions within the Acacia genus (Maslin et al. 2003), the name and integrity of Acacia pendula has remained intact for over 190 years.

Acacia pendula (family Fabaceae) is well known from inland New South Wales and Queensland, where it occurs on major river floodplains on heavy clay soils (Stanley \& Ross 1995; Kodela \& Harden 2002), in Victoria from a few small, degraded stands (Venn 2004), and the extreme eastern part of South Australia (Cowan 2001). The upper Hunter Valley of NSW is reportedly the eastern distributional limit for the species (Kodela \& Harden 2002), although in recent years it has become unclear how far east the species actually extends into this region. Taxonomically, the Acacia pendulamelvillei-homalophylla species group is complex and has not yet been satisfactorily resolved. Fensham \& Fairfax (1997) documented how identities of these three taxa have been confused in the past, and many botanists now simply refer to an 'Acacia melvillei-homalophylla species complex' in recognition of the difficulties of separating the latter two taxa. Acacia homalophylla is also very closely related to both Acacia melvillei and Acacia pendula (Cowan \& Maslin 2001), and as a consequence it is understandable that problems in identification still exist. Other species of Myall in the Hunter Valley (e.g. Acacia binervia) are distinguished from this group primarily by floral arrangement.
Taxonomic uncertainty in the populations of Acacia pendula within the Hunter Valley, including recognition of two forms (pendulous and non-pendulous habit, Table 1) that have been identified as this species over the last fifteen years, has been previously highlighted (Umwelt 2006a; Bell et al. 2007). This uncertainty is due to the uncharacteristic appearance of many of the trees in this region (the non-pendulous forms), and the lack of fertile fruit production needed to positively identify the species. For conclusive separation between Acacia pendula and its close relatives (Acacia melvillei, Acacia homolophylla), seed arrangement within fertile pods together with floral characters are necessary (Cowan 2001; Kodela \& Harden 2002). In the Hunter Valley, pod development progressing to mature seed has only been observed for the pendulous forms of Acacia pendula, while non-pendulous forms have never achieved this state (Bell 2007). Arguably, some of the non-pendulous forms of Acacia pendula may in fact represent forms or hybrid swarms of Acacia melvilleiAcacia homalophylla, which may or may not be native to the Hunter, while pendulous forms may have been planted: these issues are addressed later in this paper.

Within Commonwealth and State threatened species legislation, Acacia pendula is protected variously as a species, population and ecological community across several jurisdictions, making it one of the most protected plant species in the country. Nationally, the Environment Protection and Biodiversity Conservation Act 1999 includes Acacia pendula as a key species in the Endangered Weeping Myall Woodlands and the Critically Endangered Weeping Myall-Coobah-Scrub Wilga Shrubland of the Hunter Valley. Under New South Wales Threatened Species Conservation Act 1995 legislation, an Endangered Population of Acacia pendula is listed within the Hunter Valley (Acacia pendula, a tree, in the Hunter catchment). The species also forms a key component of the Endangered Hunter Valley Weeping Myall Woodland. Elsewhere in New South Wales, Acacia pendula is a characteristic species in the Endangered Myall Woodland in the Darling Riverine Plains, Brigalow Belt South, Cobar Peneplain, Murray-Darling Depression, Riverina and NSW South Western Slopes Bioregions. Because of separate state responsibilities, Acacia pendula is listed as a vulnerable species on the Flora and Fauna Guarantee Act 1988 in Victoria and the National Parks and Wildlife Act 1972 in South Australia. Acacia pendula is considered to be of Least Concern in the international IUCN Red List of Threatened Species due to its widespread distribution (Malcolm 2012).

Table 1. Morpho-types of Hunter Valley Acacia pendula recognised in this paper.

\section{Morpho- Characteristics \\ type}

A Small tree with grey-green or glaucous foliage; pendulous (weeping) branches; flowers and fruits freely; very occasionally root suckering

B Small tree with green foliage; slightly pendulous branches on older specimens; flowers but soon becoming infested by gall; never fruits successfully; commonly root suckering

C Small tree with green foliage; non-pendulous foliage, rounded canopy; rarely flowers, but then soon infested by gall; never fruits successfully; vigorous root suckering 


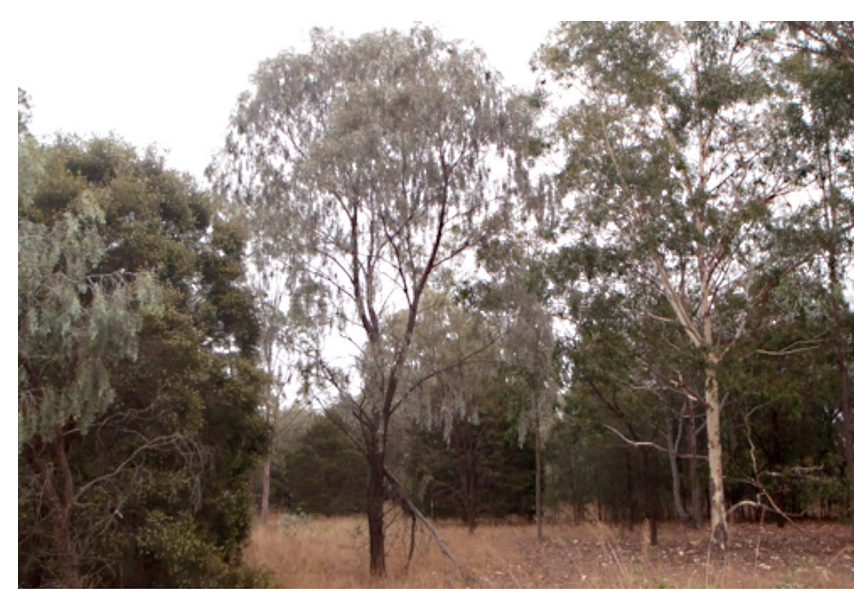

Fig. 1a. Morpho-type A (Muswellbrook)

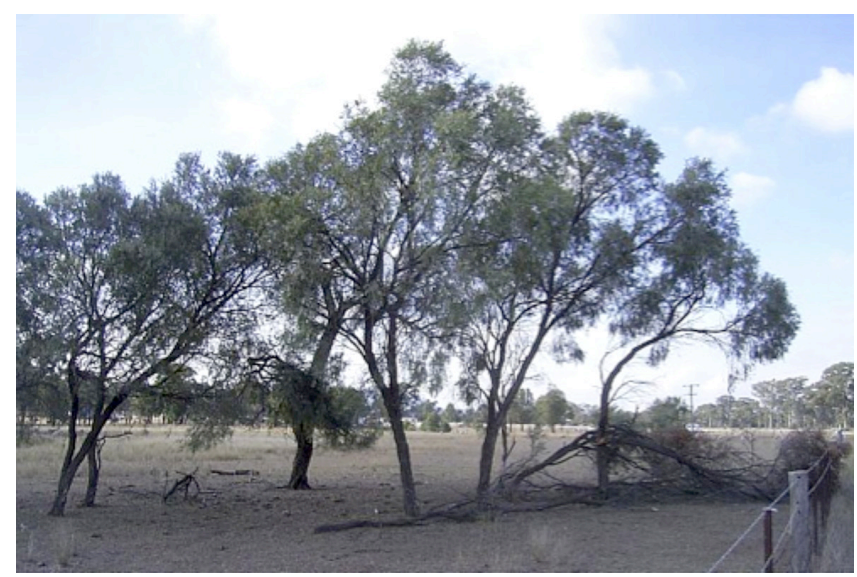

Fig. 1b. Morpho-type B (Wybong)

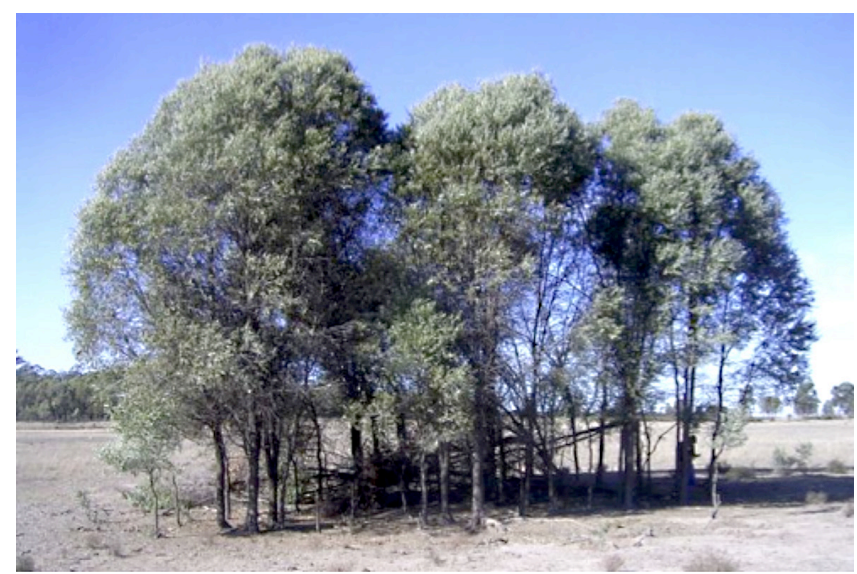

Fig. 1c. Morpho-type C (Warkworth)

Fig. 1 a-c. Morpho-types of Acacia pendula recognised in this paper for the Hunter Valley.

Surprisingly, VICDSE (2009) includes Acacia pendula in the low risk category of their environmental weed list for the Inland Plains bioregion, contrasting with its listing as vulnerable in that State.

This paper questions the presence of Acacia pendula as a 'naturally occurring' species in the region (i.e. present within the Hunter prior to pre 1788 European settlement) through three avenues of evidence. Firstly we review the writings of early Australian explorers both within and outside of the Hunter. Secondly we assess database and herbarium records in an attempt to clarify the distributional extent of this species within the Hunter Valley. Thirdly, assessments of habitat in areas currently reported to support the species are compared to documented habitat elsewhere in the range of the species. For clarity of discussion, and given the taxonomic uncertainties of Hunter specimens (Bell et al. 2007), three morpho-types (following Miller et al. 2002 for Acacia aneura) are defined, as different issues apply to each. These three morpho-types (Table 1, Figure 1) are readily recognisable in the field primarily on the basis of habit and canopy colour, and are often used by field ecologists and managers to differentiate observable forms. Throughout this paper, unless otherwise noted, Acacia pendula is applied broadly to encompass all three of these morpho-types, and is consistent with identification advice for Hunter Valley plants received from the National Herbarium of New South Wales over the past fifteen years.

\section{Study Area}

The Hunter Valley is a large coastal catchment in central eastern New South Wales (Figure 2), and one of only two low relief incursions across the Great Dividing Range. This region includes two major rivers, the Hunter and the Goulburn, which converge near Muswellbrook and flow east to the coast at Newcastle. The Hunter catchment includes all of the Goulburn, and together the two rivers comprise $21,460 \mathrm{~km}^{2}$ of diverse land uses including agriculture, urban, conservation, industrial and mining. Historically, the bulk of the valley floor and undulating slopes have been cleared for stock grazing, but in recent decades coalmining has taken up increasingly more agricultural land.

For context, it is necessary to understand the process of European settlement in the Hunter. The Hunter Valley was one of the first regions outside Sydney to be explored for arable lands, and its opening up to European settlement came from the sea via the Hunter River, and overland from Sydney (Jervis 1953a,b; Perry 1955; McMinn 1970a). In 1797 Lieutenant John Shortland charted what is now Newcastle Harbour, at the mouth of the Hunter River, followed by William Paterson in 1801 who journeyed inland along the Hunter River to near the present site of Maitland, where he and his party explored the Paterson River to around Woodville. Over a decade later, between 1817 and 1819, several explorers tried to cross the rugged country (now including the wilderness areas of Wollemi and Yengo National Parks) between the Cumberland Plain (Sydney) and the Hunter Valley. These included William Parr, Benjamin Singleton and John Howe; in 1819 Howe and his men were the first to descend out of the rugged ranges to the Hunter Valley floor, between Jerrys Plains and Denman.

Exploration of the upper Hunter Valley was also carried out from two directions; expeditions extended up the Valley from the east, and others, on the western side of the Blue Mountains, headed north and east from Bathurst. In 1822, William Lawson headed north from Bathurst in a failed attempt to find a route onto the Liverpool Plains, 
(which John Oxley had traversed from the west in 1818). Somewhere between Gulgong and Ulan, on the extreme west of the Hunter catchment, Lawson happened upon the Goulburn River, a major tributary of the Hunter. In 1823 Allan Cunningham, government botanist, searched for a pass onto the Liverpool Plains, and over the following four years made three other journeys through parts of the Hunter Valley. William Lee explored further south of Cunningham's 1823 traverse, between Denman and the headwaters of the Goulburn River in 1827.

Meanwhile in 1824, government surveyor Henry Dangar explored the land west and north of Singleton linking up the known lands of the upper and lower Hunter Valley. He reached the headwaters of Dart Brook near Scone and a pass over the Liverpool Range. In 1827, William Nowland discovered an easier route across the Liverpool Range, the Ardglen Gap near the present town of Murrurundi.

\section{Methods}

\section{Early explorers journals}

The journals of early botanical explorers are often used to elucidate vegetation patterns occurring at the time of European settlement in Australia (e.g. Benson \& Redpath 1997; Fensham et al. 2006; Lang 2008; Moxham et al. 2009). Acacia pendula was collected and described in 1817 , before exploration in the Hunter, and it is entirely plausible that some reference to this species, if present in the Hunter, would appear in some or all of the subsequent journals of early Australian explorers. This is particularly so because such an occurrence would be novel so far east from where it was known to be abundant. The aesthetically pleasing appearance of Acacia pendula trees (both individually and where it dominates a landscape) greatly aids this expectation, as early explorers often wrote about attractive landscapes.

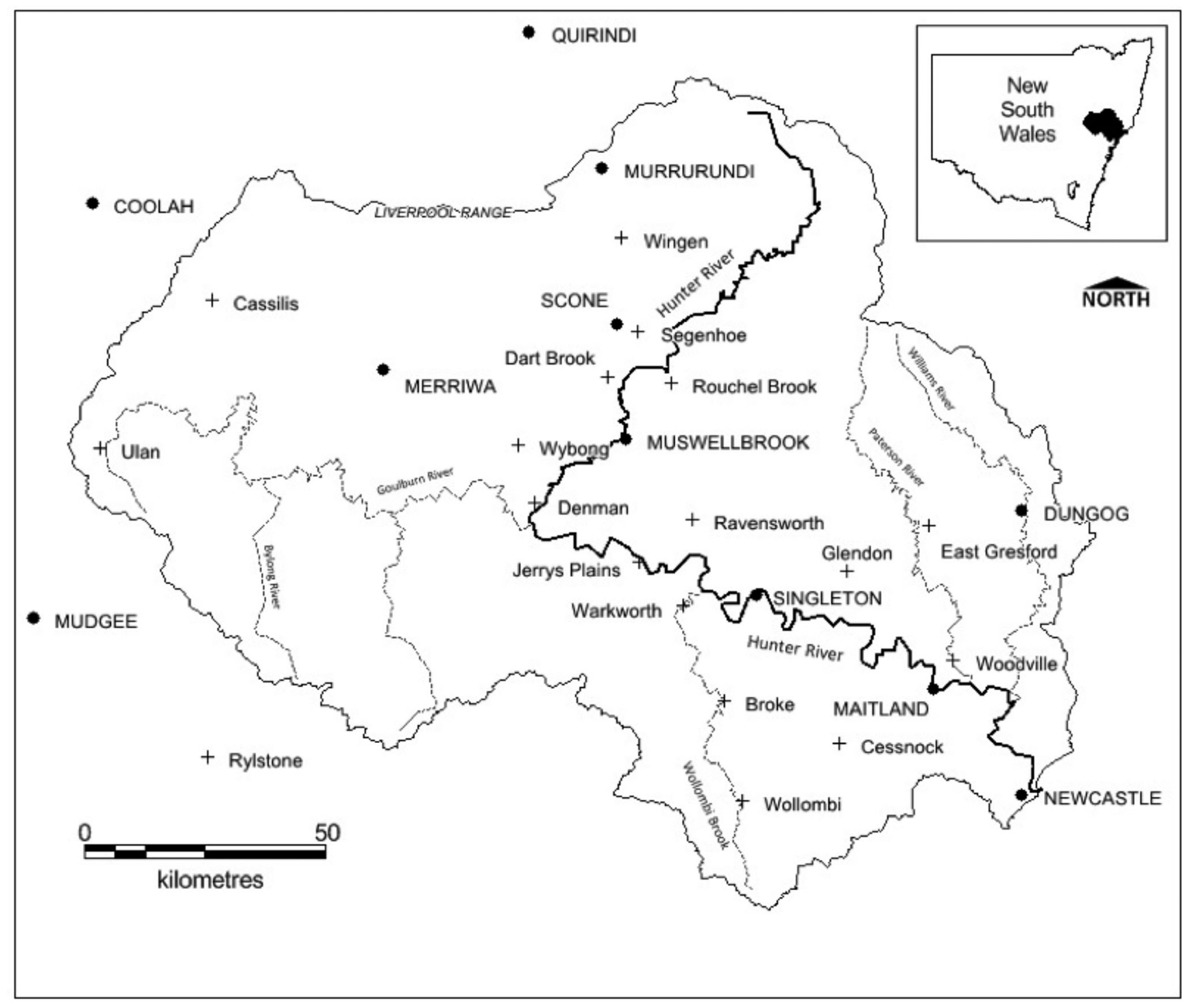

Fig. 2. The Hunter Valley in eastern New South Wales, showing waterways and locations mentioned in the text. 
Expedition journals or transcriptions of the early Australian explorers who first entered the Hunter, including those with botanical expertise such as Allan Cunningham, Thomas Mitchell and Ludwig Leichhardt, were examined for indications of the state of natural vegetation prior to European settlement. For Allan Cunningham, copies of his original journal entries were examined (Cunningham 1832a), as well as other publications (Cunningham 1825, 1828, 1832b) and the edited transcripts and commentaries contained in Lee (1925) and McMinn (1970a,b). Full accounts of the travels of Mitchell are contained in his manuscript (Mitchell 1838), while for Leichhardt the transcriptions of Aurousseau (1968) and Darragh and Fensham (2013) were the primary sources. Explorer's journals for expeditions elsewhere in Australia, but within the known range of Acacia pendula, have also been consulted to ascertain the extent to which this species was mentioned there. These include the online versions of writings and expeditions of John Oxley, George Evans, Charles Sturt, Thomas Mitchell, Edward John Eyre, Ludwig Leichhardt, William Landsborough, and several others. Other writings by early settlers, journalists and historical scholars have also been examined, including contemporary treatments of the spread of settlement and agricultural pursuits up until the present day.

\section{Database and herbarium records}

While historical journals provide important commentary on the lands explored during the 1800s, specimen collections and (more recently) digital database records of Acacia pendula provide more tangible evidence on the species distribution. Specimen collection details and digital databases were searched for Acacia pendula from two online data sources, Australia's Virtual Herbarium (AVH: http://avh.chah.org. $\mathrm{au} /$ ) and the NSW Office of Environment \& Heritage's BioNet Atlas of Wildlife (BioNet: http://www.bionet.nsw. gov.au/). The AVH is a collaboration between all nine major herbaria in Australia, and seeks to make available collection locations and notes of all Australian plant collections. Currently, over six million specimens are included in AVH. Some important historical collections (such as those of Allan Cunningham) are housed in the Kew Herbarium (London), and were searched directly from there. BioNet is a portal for accessing government-held information about plants and animals in NSW, and is supported by several NSW government agencies. BioNet is not a specimen register, but stores locality records as submitted by government and private individuals. Additional locality records for Acacia pendula not yet included in either of these two data sources were obtained from colleagues working in the Hunter Valley area.

All specimen and database records both for the Hunter Valley and the rest of NSW and Australia were examined in a Geographical Information System (GIS), to gain an appreciation of the historical distribution of this species. Where possible, all locations of Acacia pendula within the Hunter have been examined in the field by us, but in some cases the advice of colleagues has been relied upon (see Acknowledgements).

\section{Habitat assessment}

Four environmental variables were used to compare the conditions in which Acacia pendula has been recorded within and outside of the Hunter Valley: annual rainfall (30-year average, 1965-2005, from Bureau of Meteorology 2013); geological age (NSW Department of Primary Industries 2006); Australian soil classification type (NSW Office of Environment and Heritage 2013); and elevation (Gallant et al. 2011). Elevation data were in raster format while other datasets were vector format. Rainfall was summarised as $100 \mathrm{~mm}$ intervals and elevation as $100 \mathrm{~m}$ intervals. These variables are major determinants of plant distribution and were readily available in a consistent format to cover the whole of New South Wales.

Acacia pendula occurrence records from within the Hunter Valley were collated from several sources and as mentioned most had been verified by us through site inspection. Records were sourced more broadly for New South Wales (NSW, excluding the Hunter) from BioNet (http://www.bionet.nsw. gov.au/). All records were cleaned of duplicates and any NSW records with a reported accuracy greater than $1 \mathrm{~km}$ were removed. Because there was some tight clustering of records in both data sets, all were overlaid on a $100 \mathrm{~m}$ grid and the centroids of all grid cells that contained records were used to represent occurrences. This process reduced data points from 147 to 126 for the Hunter Valley, and 1082 to 646 for NSW records. The values of the four environmental values at each occurrence record were tabulated in a GIS and the data exported for analysis.

A Chi-square test of independence was used to determine whether there was a significant difference between Hunter Valley and NSW records for each environmental value. The null hypothesis was that the two data sets (Hunter \& NSW) are independent (i.e. data from one cannot predict the other). To maintain consistency with the assumptions of the Chisquared test (that $<20 \%$ of cells have an expected count $>5$ ) variables with low counts were grouped into a single variable.

\section{Results}

\section{Exploration within the Hunter Valley Allan Cunningham (1823-1827)}

Allan Cunningham, government botanist for the King, had a significant influence in the early development of Australian botany and was influential in the opening up of the Hunter (McMinn 1970a). It was Cunningham himself who first collected Acacia pendula from the Lachlan River in central western New South Wales in 1817, a species which was commonly encountered throughout central New South Wales (Oxley 1820; Lee 1925). The tree that Cunningham described near the Lachlan was the grey-green, pendulous form referred to as morpho-type A in the present paper: "Gathered seeds of Acacia pendula, nova sp., a tree 25 feet high, with much the habit and growth of Salix babylonica, leaves simple, lanceolate, the whole tree has a gray hue; common on the low flats near the above mentioned lagoon" [May 4, 1817; in Lee 1925]. 
Cunningham later undertook three expeditions through the Hunter Valley (Figure 3) during the years 1823-1827 (Lee, 1925; McMinn, 1970a,b). Despite traversing the Hunter Valley floor in the Singleton, Jerry's Plains, Denman, Muswellbrook, Merriwa and Scone districts, Cunningham did not once mention the presence of Acacia pendula until he had travelled northwest from Scone over the Liverpool Range and out of the Hunter Valley (Cunningham 1825, 1828, 1832a,b; Lee 1925). Typical of his mention of Acacia pendula were these observations from the Liverpool Plains in May 1827: "On the morning of the 11th May, we quitted our resting place and pursued a course $S$. of W. for 3 miles, at length passing round the termination of the hills through dry, brushy forest to shape a more direct line to the N.W. The wooded country was level, scarcely over 1,000 ft. above the sea-level, and at length we crossed the track of Mr. Oxley in 1818 , the observation at noon, taken in the midst of dense, drooping Acacia pendula, giving us lat. $31^{\circ} 00^{\prime} 34^{\prime \prime}$ S., which placed our position about a mile north of that gentleman's line of route to the eastward after he had forded Field's River" [May 11, 1827; in Lee 1925]; and "After penetrating brushes of the grey-hued Acacia pendula, we stretched to the N.W. about four miles over declining country, forest and open plain, with vegetation destroyed by drought..." [May 11, 1827; in Lee 1925].
After returning to the upper Hunter from the Darling Downs in 1827, Cunningham explored the Goulburn River valley (west from Denman) en route to Bathurst (McMinn 1970b). If Acacia pendula was present in abundance in any of the areas he explored in the Hunter, it seems likely that Cunningham would have noted it in his diaries. Based on extracts contained in Lee (1925), Cunningham mentions the presence of Acacia pendula on at least twenty occasions during his explorations, but not once when in the Hunter Valley.

\section{Thomas Mitchell (1831)}

Major Thomas Mitchell undertook three expeditions into the interior of eastern Australia between the years 1831 and 1836 (Mitchell 1838). Accompanying him on his journeys was botanist Richard Cunningham, brother of Allan, who ultimately met his death at the hands of Aborigines near the Bogan River. During his first journey from Sydney, Mitchell passed through Wollombi, Broke, Wambo (near Jerry's Plains), Muswellbrook, Wingen Maid (all within the Hunter; from 26 November to 5 December 1831, and back again in early March 1832) and then over the Liverpool Range onto the Liverpool Plains (Figure 3). Significantly, not once did Mitchell mention the presence of Acacia pendula until he

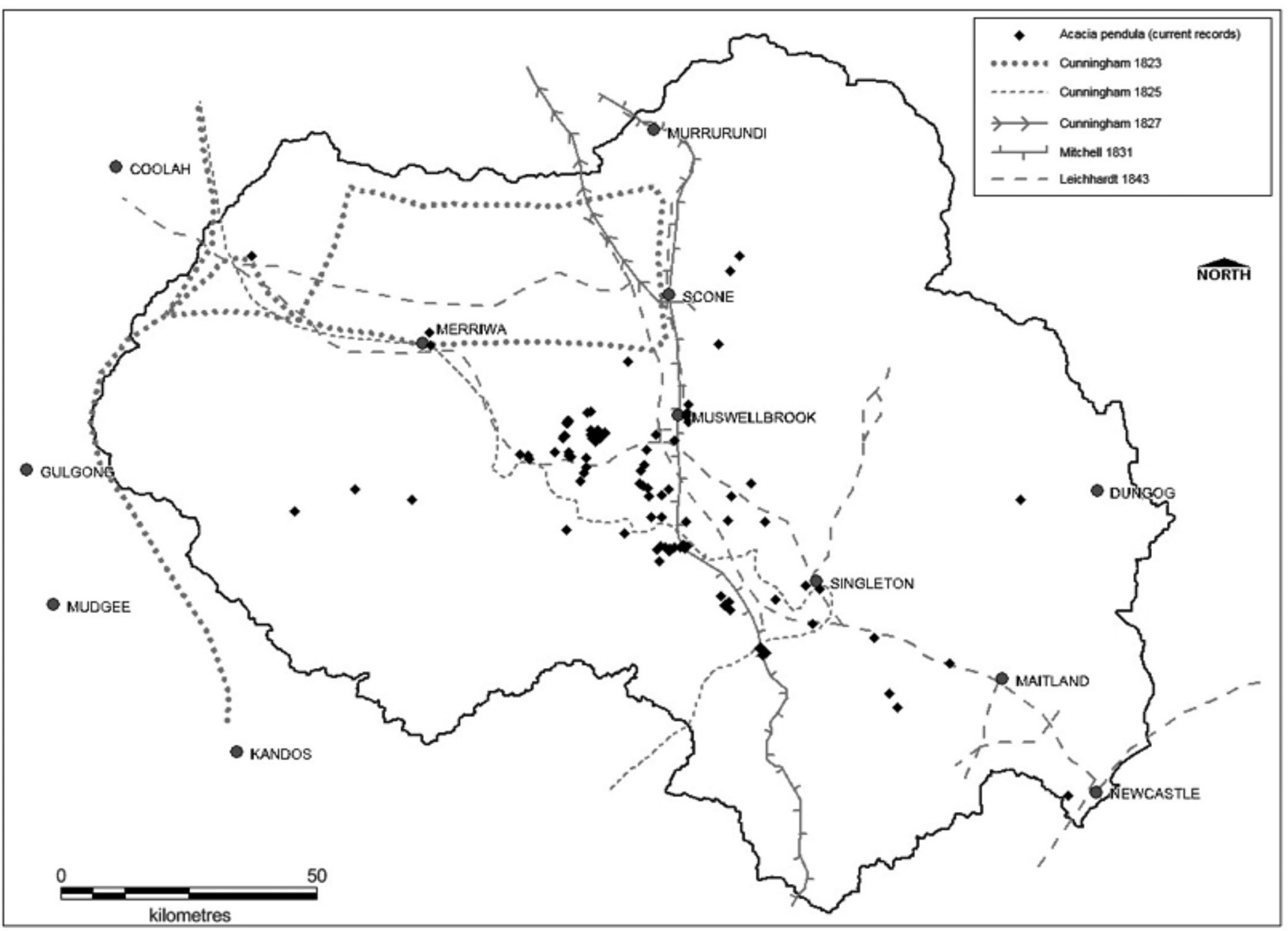

Fig. 3. Approximate main routes of early botanical explorers Allan Cunningham, Thomas Mitchell and Ludwig Leichhardt, together with current-day records of Acacia pendula (routes taken from Mitchell 1838; Aurousseau 1968; McMinn 1970b; Fallding \& Benson 2013). 
was near the Peel River, between Gunnedah and Tamworth. At this location, in December 1831, Mitchell wrote (our emphasis): "On crossing another low ridge beyond this we descended to a valley in which I saw, for the first time, that beautiful shrub of the interior, the Acacia pendula. The foliage is of a light green colour and it droops like the weeping willow; the bark is rough, and the trunk seldom exceeds nine inches in diameter. The wood of this graceful tree is sweet-scented, of a rich dark-brown colour, and being very hard, it is in great request with the natives for making their boomerangs and spearheads. It appears to grow chiefly on flats which are occasionally inundated" [December 14, 1831; Mitchell 1838]. Why would Mitchell refer to "that beautiful shrub of the interior" if he had already encountered it in the Hunter Valley?

Acacia pendula is subsequently mentioned on twentyone occasions throughout western NSW where Mitchell travelled up until 1836, particularly around the Nandewar Range and surrounding districts. He specifically noted its first occurrence since departing Sydney near the Peel River, but not before.

\section{Ludwig Leichhardt (1843)}

The German scientist Ludwig Leichhardt travelled through the Hunter en route to Moreton Bay between March and June 1843 (Darragh \& Fensham 2013; Fallding \& Benson 2013). His impressive scientific legacy from all of his travels in Australia has only come to light well after his death, where he is now regarded, like Charles Darwin, as an authentic 'man of science' (Fensham 2013), with a keen eye for scientific detail. From his lodgings at Glendon (near Singleton), Leichhardt passed through the Hunter localities of Ravensworth, Rouchel Brook, Bengalla, Wingen, Dart Brook, Myall Hill, Wybong Creek, Krui River, Cassilis, Coolah and the Liverpool Range onto the Liverpool Plains. Aurousseau (1968) shows a map of Leichhardt's journeys through the Hunter, which are included in the present paper on Figure 3. In his journal, Leichhardt first mentions Acacia pendula after leaving Bayly's Station on 25 March 1843: "Myall woodland, the black trunks and their drooping branches and leaves resemble dark weeping willows, the young saplings and bushes with stiff grey-green leaves". In his entry of 1 April 1843, he describes the species in some detail, and also outlines other "plants of the Myall brush" (Darragh \& Fensham 2013). Both of these locations are north of the Liverpool Range and outside of the Hunter Valley. Despite passing through parts of the Hunter where Acacia pendula is currently present (Glendon, Singleton, Ravensworth, Muswellbrook, Bengalla, Denman, Wybong Creek, Cassilis), these were not noted by Leichhardt in 1843. Prior to this expedition, it seems Leichhardt was already familiar with Acacia pendula from a planted specimen: on 8 April 1843 while on the Liverpool Plains describing the flower heads of Acacia undulifolia, he writes that it is "almost like Acacia pendula in the botanical garden" (presumably the Royal Botanic Gardens in Sydney).

\section{Exploration outside of the Hunter Valley}

After its original collection by Allan Cunningham during the 1817 John Oxley-led expedition, Acacia pendula was regularly remarked upon by many explorers. Between 1817 and 1862 John Oxley, George Evans, Charles Sturt, Thomas Mitchell, Edward John Eyre, Ludwig Leichhardt and William Landsborough all make reference to Acacia pendula in their writings. The frequency of these remarks throughout NSW, Queensland, Victoria and South Australia, contrast with the lack of such comments made by explorers of the Hunter Valley.

\section{John Oxley (1817)}

Surveyor-General John Oxley led two expeditions from Bathurst into the interior during 1817 and 1818. In Oxley's journals, observations on the presence of Acacia pendula were made on eleven separate occasions, often extolling the virtues of this "beautiful" tree: "On the plain, the Acacia pendula again made a very fine appearance" [June 26, 1817; Oxley 1820].

\section{George Evans (1818)}

Deputy Surveyor-General and explorer George Evans documented his observations on a short journey starting from Mount Harris (300 km north-west of Bathurst) during July 1818 (appended in letter form in Oxley 1820). In this letter, Evans notes the presence of Acacia pendula on three occasions. Shortly after leaving Mount Harris, he writes: "For six miles the country tolerably good; afterwards, to the end of my day's journey, it was alternately Acacia pendula scrubs, and cypress brushes; the soil light, and full of holes; abundance of water, but, latterly, no grass" [July 8, 1818; Oxley 1820].

\section{Charles Sturt (1828-30)}

Between 1828 and 1830, Captain Charles Sturt undertook two expeditions into the interior of southern Australia. The first journey was west to the Macquarie River and Sturt noted the presence of Acacia pendula initially in the Wellington Valley after leaving Sydney, and then a further eighteen times during this journey: "As we neared the stream we noticed the Acacia pendula for the first time,-an indication of our approach to the marshes [the Macquarie Marshes]" [December, 1828; Sturt 1833].

Sturt's second expedition travelled south-west from Sydney along the Murrumbidgee and Murray Rivers. Along the Murrumbidgee River, he first encountered the species, which was then mentioned a further six times at various points around the region. In December 1829 he wrote: "Acacia pendula now made its appearance on several plains beyond the river deposits, as well as that salsolaceous class of plants, among which the schlerolina and rhagodia are so remarkable" [December 9, 1829; Sturt 1833]. 


\section{Thomas Mitchell (1831-45)}

After leaving the Hunter Valley in 1831, Major Thomas Mitchell continued on his journey northwards, across the Liverpool Plains and onto the Darling Downs. In subsequent years, he explored along the Darling River (1835), the Lachlan River (1836) and the Warrego and Barcoo River systems in central Queensland (1845). As noted earlier, Mitchell made reference to Acacia pendula on twenty-one occasions in writings of his first three expeditions. During his fourth expedition, which attempted to locate a route between Sydney and the Gulf of Carpentaria, Mitchell noted Acacia pendula on at least thirty occasions. So embedded in his mind was this characteristic species of the interior, that he once again made note of it within a regional context: "We crossed a deep watercourse falling to the S.E.b.S. [south-east by south], and entered on a noble flat of firm rich soil, whereon grew luxuriantly, the Acacia pendula (not previously seen by us in that region), and the two best kinds of grass, Anthistiria and Panicum loevinode” [May 26, 1848; Mitchell 1848].

\section{Edward John Eyre (1840)}

In 1840, Edward John Eyre led an expedition north from Adelaide in an attempt to reach the centre of Australia. At Mt Hopeless in the Flinders Ranges, the attempt was abandoned. While in the Flinders Ranges, Eyre makes note of the presence of Acacia pendula in the area: "Late in the afternoon we reached a watercourse, which I had previously named Myall Ponds, from the many and beautiful Acacia pendula trees that grew upon its banks" [June 30, 1840; Eyre 1845]. Eyre also notes that Acacia pendula was used by the Aboriginals to make Boomerangs for hunting.

\section{Ludwig Leichhardt (1844-45)}

After his explorations in New South Wales, Leichhardt undertook a journey of some 3000 miles from Moreton Bay in Queensland, to Port Essington in the Northern Territory during 1844 and 1845. In his writings, Leichhardt often compared his observations on flora and fauna from Queensland to the Hunter Valley, confirming his familiarity with the Hunter. For example, in June 1844, he wrote a direct reference to the small upper Hunter Valley location of Wybong near Denman (and the site of some current day stands of Acacia pendula): "The country was partly rocky; the rock was a coarse conglomerate of broken pieces of quartz....; it greatly resembled the rock of the Wybong hills on the upper Hunter..." [June 13, 1844; Leichhardt 1847].

Several other references to fauna ("flying squirrel...of the Hunter"; "Jew lizard of the Hunter"), flora ("the box with long lanceolate leaves which prefers stiff flats on the tributary creeks of the Hunter"; "A species of native tobacco, with smaller blossoms than that of the Hunter..."; "A grass, well known at the Hunter by its scent resembling that of crushed ants, was here scentless..."), and previous acquaintances ("the kind support I received from R. Dawson, Esq., of Black Creek, Hunter's River...”; “....after Helenus Scott, Esq., of
Glendon, Hunter's River, who had kindly assisted me in my expedition") confirms that Leichhardt had a good knowledge of the Hunter Valley region.

Leichhardt passed through the Darling Downs in September 1844 noting: "Belts of open forest land, principally composed of the Box-tree of the Colonists (a species of Eucalyptus), separate the different plains; and patches of scrub, consisting of several species of Acacias, and of a variety of small trees, appear to be the outposts of the extensive scrubs of the interior. There are particularly three species of Acacias, which bestow a peculiar character on these scrubs: the one is the Myall (A. pendula)--first seen by Oxley on Liverpool Plains, and afterwards at the Barwan, and which exists in all the western plains between the Barwan and Darling Downs-whose drooping foliage and rich yellow blossoms render it extremely elegant and ornamental" [September 30, 1844; Leichhardt 1847]. Leichhardt postulated that Acacia pendula reached its northern most limits near Mt Lowe in central Queensland, inland from Shoalwater Bay, a fact supported by current day herbarium collections. Of interest also is his reference to the ornamental nature of Acacia pendula.

\section{William Landsborough (1862)}

William Landsborough led an expedition from Brisbane to the Gulf of Carpentaria in search of survivors from the illfated Burke and Wills expedition of 1860. Landsborough, although clearly not educated in botany, was able to distinguish between different types of Acacia, comparing one ("myall") to specimens he had seen elsewhere, and referring to them as "drooping acacia", now known as Weeping Myall. In December 1861 he wrote: "At 6.43 made one mile south to a clump of trees resembling myall, which I have seen before to the west of Rockhampton [presumably the Emerald district]" [December 12, 1861; Landsborough 1862].

Three months later, in March 1862 he noted: "Towards the river the country is wooded with a kind of myall, but not the drooping Acacia" [March 15, 1862; Landsborough 1862]. On April 29, 1862, Landsborough made the observation that Acacia pendula generally occurs on the better soils, and that their leaves make acceptable fodder for stock: "The drooping acacia grows on it. I love these trees; their foliage is so beautiful, and the wood when cut has a fine aromatic smell. The grain of the wood is nearly as hard as ebony; besides it is characteristic of the best pastoral country as it only grows on good country. Its leaves are useful and good for stock, which are fond of eating them" [April 29, 1862; Landsborough 1862].

The journals of these seven explorers testify that Acacia pendula was an easily recognisable and noteworthy species to include in appraisals of travels in central eastern Australia (1817-1862). It is mentioned on more than 100 occasions. In stark contrast this species was never mentioned in exploration undertaken by Allan Cunningham, Thomas Mitchell and Ludwig Leichhardt in the Hunter Valley in the 1820 s to 1840 s. 


\section{Database and herbarium records}

There are six sheets of Acacia pendula at the Kew Herbarium (London), including two collections attributed to Mitchell (K000806166 \& K000806167) and two to Cunningham (mounted together but duplicated on K000806169 \& K000806170). The K000806166 collection of Mitchell is annotated "subtropical New Holland" from 1846, while Cunningham's specimens are noted "Lachlan River, Cunningham 434, 1817; Hunters River, Cunningham 113, April 1825; Mitchells Expedition 1835, Nammoy [sic] River". The latter collection refers to sheet K000806167, and was not collected by Allan Cunningham (he was at that time back in England), but probably by his brother Richard who accompanied Mitchell as botanist during 1835.

The 1825 Hunters River collection attributed to Cunningham (left hand side of K000806169 \& K000806170) represents the first from the region. The label on this sheet appears in a different hand to Cunningham's, and was prepared by Robert Heward (his legatee) prior to its donation to Kew in 1862. Viewing the scanned image of this sheet it is apparent that the Hunters River specimen is morphologically quite different to both the Lachlan River and Namoi (Nammoy) River collections, and is in appearance very similar to the plants (morpho-type C) now present in the Hunter Valley (see http://apps.kew.org/herbcat/getImage. do? imageBarcode $=$ K000806169). No details of this collection are noted in Cunningham's journal, which may suggest that its presence was not considered unusual: a curiosity since Acacia pendula was commonly mentioned in journals. An alternative view is that Cunningham may have been uncertain of the identity of the specimen he collected at Hunters River, and that it perhaps represented a novel species yet to be determined. In mid-April 1825, when moving through the Denman - Mt Dangar area of the upper Hunter, Cunningham noted the presence of "[Acacia] sp. new sp. linear leaf' below sandstone escarpments, potentially referring to this collection. This linear-leaved Acacia is most likely Acacia linearifolia which grows abundantly in that part of the Hunter (not Acacia pendula), and a collection made by Cunningham in 1825 from Mt Dangar is included in the description of that species in Maslin (1994). A further possibility on the origins of the Hunters River specimen is that the label is erroneous and based on assumptions made by Heward well after Cunningham collected the material, but there is no way to determine this conclusively.

Apart from the single Cunningham specimen from 1825, $\mathrm{AVH}$ and BioNet data suggests that Acacia pendula was next recorded for the Hunter Valley in December 1932 (NSW372937; V.H. Hadley), from a property on the Merriwa Plateau. However notes accompanying this collection at the National Herbarium of NSW document the locality as Borambil, near Quirindi on the Liverpool Plains, well outside the Hunter Valley (by c. $35 \mathrm{~km}$ ). The positional accuracy of this collection is evidently in error, and it can be discounted as the first record for the Hunter. The next records for the Hunter catchment are from October 1951 at Wybong (NSW372943; L.A.S. Johnson, MuswellbrookSandy Hollow Road; shown in Figure 1 as morpho-type B), March 1964 at Warkworth (NSW372929; R. Story, Wambo Estate; shown in Figure 1 as morpho-type C), and June 1997 from the foothills of the Barrington Tops west of Dungog (CBG9710694; B.J. Wallace, East Gresford).

A note on Johnson's 1951 collection states "Trees 25 feet [7.6 m]. Branchlets drooping", while the 1964 specimen of Story is accompanied by the note "Erect, rather straggly tree up to 40 or 50 feet [12.2 or $15.2 \mathrm{~m}$ ] high, bark fibrous, fissured \& grey, suckers very freely from the roots". Neither of these two descriptions (supported by our observations at these two locations) reflects the graceful form of Acacia pendula as previously described by earlier explorers outside of the Hunter and representative of morpho-type A. The erect habit described by Story is consistent with the taxon currently ascribed to many records of Acacia pendula in the Hunter (i.e. morpho-type C), which rarely flowers and never produces fruit. A 2007 assessment (Bell 2007) of the Acacia present on the former Wambo Estate (the site of Story's collection) showed that all plants there supported the erect habit and freely root-suckering form observed by Story in 1964, and further discussed in Story (1967). Thomas Mitchell on his first journey into the Hunter Valley in 1831, passed through and (presumably) stayed at Wambo Estate, without mentioning the presence of Acacia pendula, although admittedly if it was present in its current-day form, Mitchell may not have recognised it as Acacia pendula.

The 1997 Wallace specimen (CBG9710694) from west of Dungog is of planted origin despite collection notes advising that it was natural. They state "Willow like tall shrub to c. $4 m$. Small population on stony hilltop by road. Some root suckering". Re-location of this collection site by us in 2013 revealed that Acacia pendula is naturalising from three planted specimens of morpho-type A either side of a farm gate on the Bingleburra Estate, all within a wider landscape of Eucalyptus crebra, Eucalyptus moluccana, Eucalyptus glaucina and Corymbia maculata. Bingleburra and the surrounding district of East Gresford were settled early in the 1800s (Jervis 1953a) and it is probable that these three Acacia pendula trees were planted as gate markers, and were not an original part of the local landscape. Considerable native vegetation still remains in this region but no further Acacia pendula trees have been found in the East GresfordDungog locality despite targeted searches. Elements of subtropical rainforest in gullies a mere $5 \mathrm{~km}$ to the east are inconsistent with the landscapes normally associated with Acacia pendula elsewhere in its range.

Somewhat surprisingly, between 2000 and 2012 over 75 separate location records and specimens of Acacia pendula have been lodged for the Hunter Valley, representing a 37fold increase in the total records since the first collection in 1951. Many records lodged over the past decade are in response to listing of Acacia pendula as an endangered population in the Hunter in 2005. Reductions in stock grazing pressure and the re-emergence of browsed Acacia from rootstock may also have contributed to the increased 


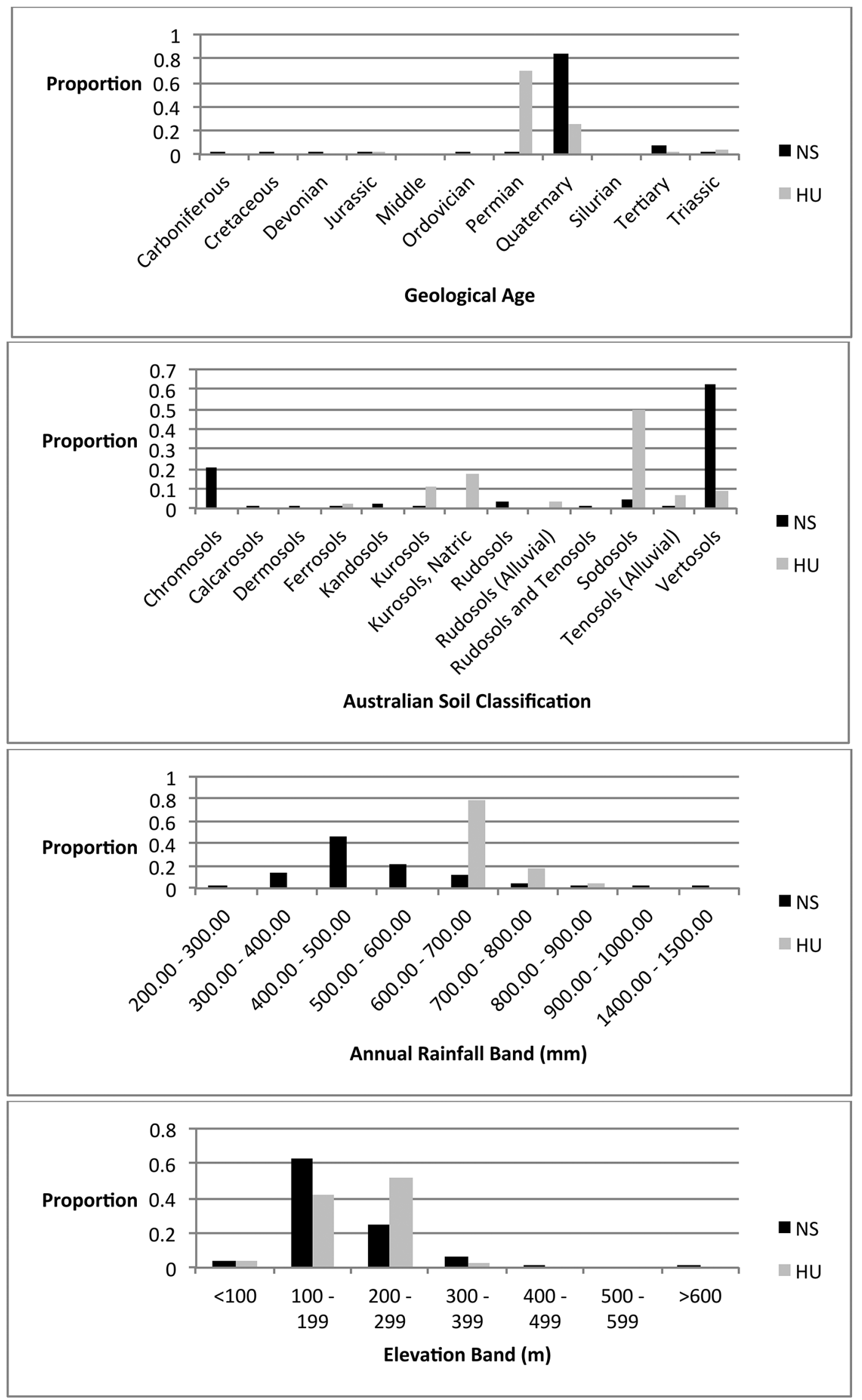

Fig. 4. Environmental analysis of geological age, soil type, rainfall and elevation of Hunter Valley (HU) records ( $\mathrm{n}=126)$ and New South Wales (NS) records $(\mathrm{n}=646)$ of Acacia pendula. 
records over the last decade. The three morpho-types are clearly recognisable in all of these records, based either on our observations at each site, or as reported by others. Importantly, we postulate that all records for morpho-type A (the 'typical' form) are of planted stock; morpho-types B and $\mathrm{C}$ are probably introduced and should perhaps not be attributed to Acacia pendula (see later).

\section{Habitat for Acacia pendula}

The first collection of Acacia pendula by Allan Cunningham in 1817 from the Lachlan River recognised the association of this species with alluvial flats: "common on the low flats near the above mentioned lagoon" [May 4, 1817; in Lee 1925]. Thomas Mitchell later remarked (our emphasis): "At two miles onward from the camp of May 14 we saw bushes of Acacia pendula for the first time since we had previously passed that place. The locality of that beautiful shrub is very peculiar, being always near but never within, the limits of inundations. Never far from hills yet never upon them" (Mitchell 1838). And again in 1848: "It [Acacia pendula] is found only in clay soils, on the borders of plains, which are occasionally so saturated with water as to be quite impassable; never on higher ground nor on any lower than that limited sort of locality, in the neighbourhood of rivers which at some seasons overflow" [December 18, 1845; Mitchell 1848]. Even those not trained in botany recognised the favoured habitat of Acacia pendula: "The drooping acacia grows on it.... besides it is characteristic of the best pastoral country as it only grows on good country" [April 29, 1862; Landsborough 1862].

Since then the link between Acacia pendula distribution and environmental traits has become well established; most current-day texts agree on the favoured habitat for Acacia pendula throughout its geographical range; Tame (1992), for example, describes its occurrence as being "usually on the heavy loams of floodplains". In the Flora of Australia, Cowan (2001) notes that it "grows mainly on floodplains on fertile alluvial clay", while Keith (2004) mentions "grey clay soils on flats and shallow depressions... far from the active channels" for his vegetation class dominated by Acacia pendula. Boland et al. (2006) states that Acacia pendula grows on depositional landforms (plains, seasonal drainage lines \& lower slopes of undulating terrain), on heavy textured clay subsoil, while Cunningham et al. (2011) describe habitat as major river floodplains and particularly on heavy clay soils. Research papers describing communities where Acacia pendula is characteristic also refer to habitats of alluvial clay soils (e.g. Benson et al. 2010).

There is also a climatic element to preferred habitat. Acacia pendula is a species of inland Australia where conditions are harsh and rainfall is low and erratic. In their overview of Acacia-dominated vegetation in Australia, Johnson and Burrows (1994) indicated that woodlands where Acacia pendula occurs occupy the annual rainfall band of 375 to 550 $\mathrm{mm} /$ year, with Queensland populations tending to be at the wetter end of this spectrum. Similarly, Keith (2004) restricts his Riverine Plain Woodlands, dominated by Acacia pendula, to the $375-500 \mathrm{~mm} / \mathrm{yr}$ rainfall band. The Hunter Valley receives considerably more rainfall than this, with figures ranging from
$611 \mathrm{~mm} /$ year at Scone, to $716 \mathrm{~mm} /$ year at Cessnock (Bureau of Meteorology 2013).

\section{Comparison of environmental features of NSW and Hunter Valley populations}

Comparison of Acacia pendula records from the Hunter Valley with those from elsewhere in NSW showed significant differences between the environmental features across these two regions. Figure 4 shows frequency distribution histograms for each environmental variable tested. The Chi-square test of independence showed that these differences were all significant $(\mathrm{p}<0.001)$. For the Hunter Valley, the majority of records for Acacia pendula lie on Permian sediments, in Sodosol or Kurosol soils, at elevations of 200-299 m, and within the $600-800 \mathrm{~mm} / \mathrm{yr}$ rainfall band. For other parts of NSW, most records lie on Quaternary sediments, in Vertosol or Chromosol soils, at 100-199 m elevation, and within the $300-600 \mathrm{~mm} / \mathrm{yr}$ rainfall band.

\section{Discussion}

Despite listing of Hunter Valley populations of Acacia pendula in threatened species legislation, there is some doubt regarding the presence of this species within the region prior to European settlement. This paper raises important questions concerning the presence of this species in the region, questions that have significant implications on the conservation of this species in the Hunter Valley, and point to the need for urgent genetic assessments of the Acacia pendula complex.

\section{Did Acacia pendula occur naturally in the Hunter?}

Based on the evidence from historical writings, database and herbarium records, and habitat characteristics, it seems unlikely that Acacia pendula ever occurred naturally within this region. There are no collections or records of Acacia pendula held in databases or herbaria (except for the 1825 collection of Cunningham which may be erroneous) for the first 128 years of botanical exploration (1823-1951). Two putative records from 1951 and 1964, at Wybong and Wambo respectively, potentially represent the first Hunter records, but these were collected in well-established grazing lands when settlement of the upper Hunter was virtually complete (Perry 1955; O'Rourke 2009). Allan Cunningham (between 1823 and 1827), Thomas Mitchell (1831) and Ludwig Leichhardt (1843), all early pioneering Australian botanists and explorers familiar with Acacia pendula, had travelled through the Hunter Valley, including the Wybong and Wambo districts, but none of them made reference to the species. The plethora of Acacia pendula records between 2000 and 2012, in areas previously well explored botanically, raise the issue of how a longlived, resilient and attractive tree, growing widespread across suitable habitat elsewhere, remained effectively unobserved and uncollected for 180 years.

Similarly, the historical record as presented in this paper strongly suggests that Acacia pendula was not present during the European expansion into the Hunter Valley in the early 
1800s. More contemporary studies are also revealing. Cameron (1935), for example, notes in her regional assessment of NSW vegetation that, "The region of the Upper Hunter, as before mentioned ( $p .24)$, is most interesting, for several distinctly western species are recorded for that area, of which the following are of importance: Acacia homalophylla (Yarran), Acacia harpophylla (Brigalow), Acacia salicina (Cooba), Geijera parviflora (Wilga), Casuarina luehmanni (Bull Oak), Heterodendron oleaefolium (Rosewood), Pittosporum phillyraeoides (Butter Bush) and Eucalyptus camaldulensis (Murray Red Gum)." Notable by its absence is Acacia pendula, which if present in the Hunter during the 1930s would surely be mentioned in this context. Continuing, Cameron (1935) states that the western boundary of her region $2 \mathrm{c}$ (which lies well west of Mudgee, and beyond the Hunter) "marks the beginning of the transition region (3), where flourish such trees as Acacia homalophylla, Acacia pendula, Geijera parviflora, Heterodendron oleaefolium and Eucalyptus populifolia”. Later assessments of NSW vegetation, most notably that of Keith (2004) and the NSW Vegetation Classification and Assessment (NSWVCA: Benson 2006), recognise four units dominated by Acacia pendula. Only Benson et al. (2010) defines a community for the Hunter, the Weeping Myall - Coobah - Scrub Wilga Shrubland of the Hunter Valley, centered on the cemetery at Jerrys Plains.

In the first regional vegetation assessment of the Hunter Valley, Story $(1963 \mathrm{a}, \mathrm{b})$ discussed twelve major vegetation types, but none of these contain Acacia pendula. His discussions on savannah woodlands of box gum and ironbark make no mention of any Acacia tree species characterising them, although other small tree and shrub genera are noted (e.g. Allocasuarina, Brachychiton, Bursaria, Callitris, Canthium, Daviesia, Exocarpos, Santalum, Notelaea). For part of his Rouse savannah land system, a community dominated by the small tree Acacia doratoxylon is noted, but few other Acacia-dominated examples are evident. The total list of Acacia species recorded by Story (1963b) includes twentyfour taxa, including ten tree species, but no Acacia pendula (A. crassa, A. dealbata, A. deanei, A. doratoxylon, A. irrorata, A. melanoxylon, A. parvipinnula, A. prominens, A. salicina, A. schinoides). It is not until later when examining soil-water relations in partly cleared woodlands that he discusses Acacia pendula on the Wambo Estate near Warkworth (Story 1967). Given that the Warkworth area was one of the first districts in the Hunter settled and cleared by Europeans in the early 1800s (Lucas 2013), there is little evidence to suggest that by 1967 the Acacias examined by Story were naturally occurring. Tame's (1984) classification of the Hunter Valley vegetation makes no mention of Acacia pendula.

Over recent years, considerable effort has been expended on understanding the regional patterns in native vegetation within the Hunter Valley (e.g. NSWNPWS 1999, 2000; Peake 2006; Sommerville 2010; Sivertson et al. 2012). These projects have used numerical analysis of systematic sample data to delineate and map vegetation communities, and to illustrate trends in the distribution of plant species. Based on these studies, the Hunter Valley floor comprises vegetation systems dominated by Spotted Gum (Corymbia maculata), Ironbark (Eucalyptus fibrosa, E. crebra), Redgum (Eucalyptus tereticornis, E. blakelyi, E. camaldulensis) and Box (Eucalyptus moluccana, E. albens, E. dawsonii, E. melliodora). Alluvial soils support Redgum, Roughbarked Apple (Angophora floribunda) and Oaks (Casuarina cunninghamiana, C. glauca). Alluvial plains and flats characterised by Acacia species, such as occurs inland of the Great Dividing Range, are not present in the catchment. It is incongruous that early explorers of the Hunter would have travelled through mile after mile of the ubiquitous ironbark, spotted gum, redgum, apple and box, and not made comment on the contrasting presence of Acacia pendula if it were there.

Early explorer accounts also lend support to the vegetation systems currently observed in the Hunter, highlighting regional differences within and outside of the catchment. Aurousseau (1968, in Benson \& Redpath 1997), for example, quotes Ludwig Leichhardt: "Between the Peel and Namoi the forest changes, and instead of riding between spotted gums, box and narrow-leaved ironbark you enter a forest of silver-leaved ironbark whose leaves are greenish grey ...". As noted above, this combination of eucalypts is typical of much of the Hunter Valley floor, and a check of the distribution of these species on Australia's Virtual Herbarium, particularly spotted gum (Corymbia maculata) and narrow-leaved ironbark (Eucalyptus crebra), suggests that perhaps Leichhardt was actually referring to his exit from the Hunter for the observed change. Further, Leichhardt writes: "Just as the brigalow gives character to this part of the country [south-west of Brisbane] another species of Acacia, the myall (Acacia pendula) characterises the Liverpool plains and the plains of the Gwydir and the Big River ...". Leichhardt did not include the Hunter in this comparison, despite his familiarity with the region.

The alluvial plains of the Hunter and Goulburn valleys, where it may be expected Acacia pendula would occur, have long supported other vegetation types, as evidenced in the writings of Dumaresq (1827) for the Muswellbrook area (our emphasis): "We tethered our horses in the heat of the day; and, after lighting a fire and making tea for the last time, took a siesta for a couple of hours by the side of the creek, under the shade of a large apple-tree, which is the most common tree met with in these parts. It is not the apple-tree of Europe, but the Angophora [Angophora floribunda] of Linnaeus, and it is a certain indication of a fruitful soil."). Cunningham also frequently spoke of Apple-trees and Apple-tree flats in his writings. Today, Angophora floribunda is a common remnant tree of creeklines and lower slopes in the Hunter, where it has not been overly cleared for grazing.

\section{Do ecological traits of Acacia pendula concur with Hunter stands?}

Most reference texts agree that a pendulous habit is typical for Acacia pendula, and is a characteristic commonly used in identification. However, for Acacia melvillei and Acacia homalophylla (and many other arid-zone Acacias), the pendulous tendency is also a feature to varying degrees. Boland et al. (2006), for example, state that "Yarran [A. homalophylla] is less pendulous than Myall [A. pendula] and has a strong propensity to form clonal clumps via root 
suckering". The root-suckering habit is not often noted in other texts, but virtually all of the non-pendulous forms of Acacia within the Hunter show vigorous root suckering. That young plants of Acacia pendula are not pendulous, but acquire a pendulous habit when approximately $2 \mathrm{~m}$ high has been reported by Umwelt (2006a). Leichhardt noted this trait as early as 1843: "the young saplings and bushes with stiff grey-green leaves".

Based on limited field observations, Maslin and McDonald (2004) stated that some Acacia species which have the ability to root sucker do so more readily when they grow in areas marginal to their preferred habitat, or when adverse environmental factors prevail (e.g. severe insect predation, severe frost, prolonged drought, fire, etc). Some species, Acacia saligna for example, apparently rarely root sucker in cultivated stands but in nature sucker regrowth is common. However, there may be other processes involved. The superficially similar Acacia aneura (Mulga) is a very complex group, and has been the subject of intense study in recent years (Miller et. al., 2002; Page et al. 2011). Apomixis (replacement of sexual reproduction by asexual reproduction, such that genetic identities of progeny are identical to the parent) and neotony (retention of juvenile features in the adult phase), as described by Miller et al. (2002), may also be impacting on Acacia pendula in the Hunter and exacerbating identification problems.

Many stands of Acacia pendula in the Hunter occur in areas depauperate in understorey and ground layer vegetation, a feature not evident in stands further west (e.g. Porteners 1993). Allelopathy (the inhibition of germination and growth of other plants through the release of chemicals into the environment) may be acting in these cases; this will influence the diagnosis and recognition of a community characterised by Acacia pendula (such as those Hunter Valley communities currently listed under legislation). Typically, the more hardy and adaptable species are likely to overcome such localised changes to the environment, while others will succumb. Most chemical compounds released by plants are secondary substances produced as a by-product of primary metabolic processes, some beneficial to other plants and some harmful (Lorenzo et al. 2010). While Acacia pendula is not yet reported to be allelopathic, many other Acacia species are (e.g. Hameed et al 2011; Lorenzo et al. 2012).

Root competition may also be an explanation in those situations where ground vegetation is sparse, and critical resources such as water availability is limited. For example, Harris et al. (2003) investigated the inhibitory effects of White Cypress Pine (Callitris glaucophylla) on the growth of ground layer vegetation in south-eastern Queensland. They suggested that, rather than pine litter inhibiting germination and growth of ground cover species, high root competition in dry environments may be responsible. Similar results were reported in Allocasuarina luehmannii in semi-arid regions by Morgan et al. (2013). For Acacia pendula, Story (1967) discussed the impacts of root competition on the growth of pasture grasses around this species in the Hunter Valley, and concluded that root competition was the most likely cause of bare areas under canopies.

\section{Was Acacia pendula planted for aesthetic purposes or stock-browse?}

Given the lack of historical references to Acacia pendula in the Hunter, it is reasonable to assume that many of the plants now present originate from plantings, much like those occurring in the Bathurst district (http://plantnet.rbgsyd.nsw.gov.au/ floraonline.htm). This is particularly the case for specimens of morpho-type A, which is a commonly used horticultural subject. NSW State Forests long maintained a plant nursery at Muswellbrook in the upper Hunter Valley, which stocked and sold this species for several decades. An advertisement in the Singleton Argus of 4 August 1947 recommends the planting of Acacia pendula in the Hunter district, following the advice of the Forestry Commission of NSW (Anon 1947). Because of the attractive weeping foliage of this tree (Boland et al. 2006) it has been commonly used throughout the region in avenue and screen plantings. Within the Hunter Valley, good examples occur along the Golden Highway on the eastern approach to Merriwa, along the New England Highway at Ravensworth, Denman Road between Denman and Muswellbrook, within salinity trials at Wybong, along Range Road in the Singleton Army Training Area and at Cessnock airport. In Victoria, Acacia pendula is reported to have originally been naturally rare (Keith 2004; McDougall 2008), but plantings as long as 100 years ago have clouded knowledge of natural stands (Venn 2004) and genetic studies are required for clarification. Interestingly, records of the similar arid-zone species Acacia aneura from the upper Hunter Valley, although included in distributional information, are suspected by the National Herbarium of NSW to have been introduced (http://plantnet.rbgsyd.nsw.gov.au/cgi-bin/NSWfl.pl ?page $=$ nswfl $\& l v l=$ sp\&name $=$ Acacia $\sim$ aneura $)$.

Plantings of various species have a long history in the Hunter. Breton (1833), for example, during his journey through the region made reference to a land owner in the Muswellbrook district and his penchant for planting various trees and shrubs, suggesting that as early as the 1830 s some settlers were already introducing non-endemic and exotic species to the region: "Twelve miles farther is St Hiliers, one of the finest estates on the Hunter; the house is the best in the district; and as the proprietor is constantly engaged in planting the most useful and ornamental trees (one of the very few instances I have seen in the 'bush'), the place bids fair to remind him, at no very distant period, of an English country house with its shrubberies". And indeed, Breton (1833) actively encouraged further planting of trees (both native and of European extraction) to potential new settlers: "I cannot but think the colonists might more generally introduce the various European trees upon their farms ... Even by encouraging clumps of acacias, the appearance of the country would be improved ...". During the late nineteenth century, Joseph Maiden contributed greatly to the movement of Acacia specimens and knowledge throughout the colonies and the World, including the recommendation of certain species for planting within New South Wales (Frawley 2010).

Jerrys Plains cemetery is a key location mentioned specifically in NSW and Commonwealth threatened species legislation, but it is likely that Acacia pendula stands there originate from earlier plantings or escapees. No mention of the species was made by Allan Cunningham, Thomas 
Mitchell or Ludwig Leichhardt, all of whom were familiar with the species and moved through the area between 1826 and 1843. Potential habitat for Acacia pendula in Jerrys Plains would most likely be those flats in proximity to the Hunter River, about which a visitor to Jerrys Plains in 1827 remarked: "a particularly rich and beautiful strip of narrow land, formed by the alluvium of the river, and the debris of the mountains. This little tract extends westward about ten miles along the river, and astonishing to say, is comparatively unknown by the settlers, either new or old." (cited in Jervis 1953a, p. 105). However, the cemetery site is located well upslope from these alluviums, on a gently sloping hillside of Permian clays, and it would seem unlikely to have once naturally supported Acacia pendula.

During preparation of a management plan for the Jerrys Plains cemetery site, Umwelt (2006b) reviewed historical aerial photographs and found that most woody vegetation had been cleared in 1954 and again in 1958, so that current day vegetation represents about 50 years of regeneration. It is likely that clearing of vegetation has occurred intermittently since at least 1890 (the time of first burials), and quite possibly earlier than that. A notice in the Singleton Argus newspaper of 30 October 1895 pertains to the clearing of the cemetery to which it was "put into something like decent appearance" (Anon 1895). Current-day stands of Acacia pendula consequently lie at a location that has been regularly cleared and managed for at least 120 years, and raise further doubts over the origin of the plants growing there.

For the more unattractive morpho-types $\mathrm{B}$ and $\mathrm{C}$, evidence for plantings of Acacia pendula as stock-browse specimens is perhaps more informative. Pastoralists soon recognised the browse potential of Acacia pendula, as evidenced in the writings of Ludwig Leichhardt, Thomas Mitchell and William Landsborough during the mid 1800s. In his many observations on the behaviour and habits of cattle, Leichhardt noted on 16 May 1843 that "In the myal forest grows a shrub that the cows eat with great appetite, although they can live off the myal". Mitchell (1848) writes: "The Acacia pendula, a tree whose habitat is limited and remarkable, is much relished by the cattle. .... In such situations, even where grass seems very scarce, cattle get fat; and it is a practice of stockmen to cut down the Acacia pendula (or Myall trees, as they call them) for the cattle to feed on". Later, Landsborough (1862) observed that: "Its leaves are useful and good for stock, which are fond of eating them". Such observations are supported by more contemporary writings, extolling the nutritional value of Acacia phyllodes and pods as stock-browse (e.g. Dynes \& Schlink 2002). Indeed, Butler (2007) noted that Acacia pendula, along with several other arid-zone species within Brigalow (Acacia harpophylla) vegetation communities, are readily eaten by domestic stock and native or feral herbivores. Much like Kurrajong (Brachychiton populneus) in other areas, lopped trees were often used as forage during drought periods (Froggatt 1923; Goodchild \& McMeniman 1987; Cunningham et al. 2011).

An alternative explanation relating to the presence of morpho-types B and C may be the misidentification of stockbrowse. For example, in the initial inspections of Acacia for an Environmental Impact Statement at the Wambo mine at Warkworth (the former Wambo Estate established by James Hale in 1824), plants were identified initially as Acacia aneura but are now referrable to Acacia pendula. (recounted in Bell 2006, and in keeping with the identification of these trees advanced by Story 1967) Given many authors (e.g. Fox 1987; Boland et al. 2006) note Acacia aneura (Mulga) as being the most important fodder tree in Australia, it is quite plausible that early pastoralists mistakenly collected seed or cuttings of an Acacia species from inland areas, thinking it was Acacia aneura, to establish fodder trees on their holdings for future drought relief. Indeed, the photograph of Acacia aneura in Boland et al. (2006, p. 135) bears a strong resemblance to Hunter Valley plants currently referable to morpho-type C.

\section{Was Acacia pendula accidentally introduced?}

During the 1820 s to 1840 s, land grants in the Hunter Valley were made to wealthy pastoralists, who were seeking respite from drought-affected grazing lands in the Hawkesbury and Sydney districts. From the Hunter, further exploration onto the Liverpool Plains was made by these pastoralists (generally following the route taken by Mitchell in 1831: see Figure 2), where new grazing properties were established (Ellis no date), often without the sanction of Government. In 1827, James Robertson (Plashett estate, Jerry's Plains) was one of the first men to drive sheep and cattle across the ranges onto the Liverpool Plains, locating and establishing properties at Mooki Springs and along the Namoi River (Hunter 2010). He would later bring stock back to the Hunter for fattening and marketing. Similarly, David Brown and family relocated to Jerry's Plains from Cattai (northwestern Sydney) in the early 1830s, to be more central for their push to the north-west and the Liverpool Plains (Griffiths 2012). During the 1830s, the Brown family drove fattened cattle from the Gwydir/ Namoi Rivers area, south through what are now the townships of Narrabri, Turrawan, Boggabri, Gunnedah, Mururrundi, Scone and Muswellbrook to Jerrys Plains. Jerrys Plains was used as a staging point for sending cattle to the Maitland or Newcastle markets, or along the Bulga track to Windsor (Griffiths 2012). James Hale (Wambo Estate, Jerrys Plains) and George Bowman (Arrowfield, Jerrys Plains) also undertook cattle runs from the Hunter to the Gwydir, where they too established grazing properties (Lucas 2013). In 1866, an entry in Bailliere's Gazetteer stated of Jerry's Plains: "The town is so situated that all the fat stock from Queensland and the Bogan pass through it" (in Ellis no date).

Periods of drought were influential in drives such as these to search further afield for grazing lands. Griffiths (2012) cites an article from the press of August 8, 1846: “..the cattle still suffer greatly from want of water, there being none anywhere, but in the river, within miles of which there is not a blade to be seen". During this time, cattle were fed the leaves of "the oaks growing by the side of the river", presumably River Oak (Casuarina cunninghamiana). Popinjay (1990), recounting articles to The Australian newspaper from October 1827 concerning Jerry's Plains, writes that the area was “...generally abounding in rich grass, but now, after a 
six months' drought (August) and depasturing two or three thousand head of cattle, it is for the most part brown and bare, and partakes more of the character of an extensive stock-yard, than a district justly celebrated for its rich and abundant pasture". Such comments are later supported by Breton (1833): “... during the 'great drought' (1826, 27, $28,29)$ not a blade of grass was visible, except in shady spots ...". Alternative grazing lands outside of the Hunter were therefore seen as a necessity to circumvent the perils of drought years. In many cases, holdings on the Liverpool Plains were extensive, such as the 300,000 acres owned by Samuel Clift in the 1840 s, easily eclipsing his 5,000 acres in the Hunter during the preceding decade (Ellis no date).

Given the widespread current-day occurrence of morphotypes $\mathrm{B}$ and $\mathrm{C}$ in agricultural lands in the Hunter, it is perhaps more plausible that these plants were introduced accidentally through stock movements such as between the Hunter and Liverpool Plains. A number of Acacia species are known to be consumed by large herbivorous mammals, and when seeds and pods are ingested there is potential for long-distance dispersals to occur (Razanamandranto et al. 2004). This process, endozoochory, allows for the acidic conditions and enzymes present in the rumen and large intestine of mammals to scarify the seed surface, such that seed germination is possible after the deposition of faeces in favourable environments (Haameyer et al. 2010). In their study on Argentinean Acacia species, Venier et al. (2012) concluded that the structure of the seed coat in hard seeded species is crucial to the success of endozoochory, supporting the results of earlier studies on other legumes (e.g. Gardener et al. 1993; Danthu et al. 1996; Shayo \& Uden 1998). Commonly, when Acacia pods and seeds are eaten by cattle, seeds pass through the digestive tract unharmed as they are protected to some extent by pod structure (Miller \& Coe 1993).

During the early days of settlement in the Hunter Valley, fencing was limited to areas immediately around homesteads, allowing stock to roam freely (Ellis no date) across wide areas, tended by shepherds. As early as 1829 , there were reportedly 119,391 head of sheep, 46,805 head of cattle and 1,316 horses in the region (Jervis 1953a). It is not unreasonable to assume, therefore, that once Acacia species had been introduced into the region, their dispersal via livestock across the valley was relatively unregulated. In one study of the introduced Acacia nilotica in the Northern Territory, Radford et al. (2001) describe the paddock-scale dispersal of this species by cattle, which readily consume and spread viable seed through their faeces. Paynter et al. (2003) reported that the seed of this species take 6 days to move through the gut of cattle, and that $40 \%$ of seed passed in this way were viable. In the Sudan, Razanamandranto et al. (2004) postulated that the 15-30 km daily movement by livestock could play a major role in the long-distance dispersal of Acacia species there. It is more than feasible that consumption of seeds of Acacia pendula and other arid-zone Acacias by cattle, followed by 6 days of travel (either from the Liverpool Plains to the Hunter, or within the Hunter Valley itself), could result in the introduction and spread of viable Acacia seed to the region. During the 1870s, cattle were permitted by licence to travel no more than 10 miles (16 $\mathrm{km}$ ) per day along designated travelling stock reserves (Smiles et al. 2011), meaning that nearly $100 \mathrm{~km}$ could be traversed before Acacia seeds were deposited in cattle dung. Prior to 1870 , daily distances travelled may well have been longer.

\section{Is Acacia pendula naturalising in the Hunter?}

During investigations undertaken for this paper, it has been observed that some planted specimens of Acacia pendula in the Hunter (morpho-type A) are showing signs of naturalisation, particularly in those situations where ground disturbance has occurred. Good recruitment and/ or root suckering has occurred at the Bingleburra (East Gresford) population (Figure 5), the Singleton Army Training Area and at a disused farm near Muswellbrook. These populations are characterised by a few taller, older trees amongst younger plants, and have all flowered and fruited shedding seed into the immediate locality. Ground disturbance, such as the grading of road edges by machinery or lawn mowing, has promoted seed germination. At the Muswellbrook site, an original row of eight specimens (now $\sim 12 \mathrm{~m}$ in height) planted near an old homestead have seeded abundantly and created a stand approximately 40 x $90 \mathrm{~m}$ in size (Figure 6). Previous earthworks evident within the original stand of trees have likely promoted germination of the seed bank. The passage of fire through any of these stands supporting planted specimens of Acacia pendula would presumably promote mass seedling emergence.

Acacia pendula has not previously been reported naturalising in regions outside of its accepted distributional range, although VICDSE (2009) includes the species in the low risk category of their environmental weed list for the Inland Plains bioregion (a curiosity, since this species is also listed as threatened in Victoria). However, a number of other Acacia species have done so, most notably Acacia baileyana, A. cyclops, A. dealbata, A. decurrens, A. longifolia, A. pycnantha, A. saligna and A. sophorae (Costello et al. 2000; Morgan et al. 2002; Emms et al. 2005; Eichhorn et al. 2011; Millar \& Byrne 2012). In his review of introduced plants in Australia and their weed status, Randall (2007) includes forty-three native Australian Acacia species which have naturalised beyond their accepted geographical ranges. Within New South Wales, recent papers by Hosking et al. (2003; 2007; 2011) have included only Acacia pulchella var. pulchella as showing evidence of recent naturalisation. Over time, naturalisation of native Australian species outside of their original distributions can present complexities for management and conservation planning, particularly when those species are threatened taxa (cf. Rocha \& Bergallo 2012). Given the propensity for ornamental planting of Acacia pendula, it is surprising that naturalised populations have not been reported previously.

The seed of Acacia pendula is evidently hard, and requires some form of pre-treatment to induce germination. Ghassali et al. (2012) evaluated four stratification techniques (water, boiling water, sulphuric acid, mechanical scarification) on the seed of 14 species of Acacia, and found that mechanical scarification produced the highest germination rate in Acacia pendula. This finding is supported by that of Cromer (2007), who found that treatment of seed by boiling water resulted 
in only $15 \%$ germination success. Based on the germination studies of Larsen (1964) and Aveyard (1968) for Acacia pendula, Auld (1986) indicated that scarification produced the highest germination rates $(>80 \%)$, followed by boiling water treatment $(<70 \%)$, the addition of acid $(<70 \%)$, application of dry heat $(\sim 40 \%)$, or with no seed treatment $(\sim 30 \%)$. This would suggest that, for example, any grading of roadside populations of Acacia pendula will likely result in fresh germination from the seed bank. Conversely, seed falling in a grassy paddock is unlikely to result in mass germination without scarification. Interestingly, Froggat (1923) in discussing the Bag Shelter Moth (Teara contraria), suggested ready germination of Acacia pendula where it is protected from grazing stock: "Wherever land is enclosed and protected from stock, these acacia seedlings spring up in such numbers as to form regular thickets, and the homestead and horse paddocks are usually ornamented with groups of these trees on all the western stations". It is likely that the seedlings that Froggat refers to here are actually resprouts from root suckers, appearing after the removal of grazing stock, rather than freshly germinated seed. Such an assumption commonly occurs today for stands of Acacia pendula that have had grazing pressures removed (e.g. Bulga Coal Management Pty Ltd 2013).

\section{Could there be an undescribed new Acacia species in the Hunter?}

The available evidence suggests strongly that Acacia pendula (morpho-type A) has never existed naturally in the Hunter Valley. If this is the case, then what becomes of the many small stands of trees and shrubs currently attributed to this species (morpho-types B \& C) that have surfaced in the region since 2000 ? There is a slim possibility that these represent an as yet undescribed new species of Acacia worthy of protection, but this is difficult to confirm when flowering is typically aborted prior to fruiting. All records occur in heavily grazed lands and none are within intact natural bushland, so it would appear more likely that the plants have been introduced and the unfavourable habitat is manifesting itself in vigorous root suckering, neotony and apomixis. Nevertheless, the similarly clonal Acacia atrox from the North Western Slopes of NSW has likewise not been recorded in fruit (Kodela 2001; Copeland \& Kodela 2012), but is currently treated as a distinct species and listed as a threatened species. Genetic studies will be necessary to resolve this issue satisfactorily, but at present it is clear that these Hunter Valley plants are not Acacia pendula. Until resolution has been achieved, there may be precautionary merit in retaining some level of conservation significance over morpho-types B \& C.

\section{What are the conservation implications of the absence of evidence for natural stands of Acacia pendula in the Hunter?}

These primarily reflect the current listing of the species in various threatened species legislations, the protection such listings impose on the species, and the provision of restoration funding that these listings currently attracts. Within the Hunter Valley, Acacia pendula is protected as an Endangered
Population (NSW TSC Act) and is a characteristic component of a vegetation community listed in New South Wales (the Hunter Valley Weeping Myall Woodland) (NSW TSC Act) and Commonwealth legislation (the Weeping MyallCoobah-Scrub Wilga Shrubland of the Hunter Valley)(EPBC Act). Elsewhere in New South Wales, Acacia pendula is also included in an Endangered Ecological Community, Myall Woodland in the Darling Riverine Plains, Brigalow Belt South, Cobar Peneplain, Murray-Darling Depression, Riverina and NSW South Western Slopes Bioregions (NSW TSC Act). This community cannot apply fully to stands of Acacia pendula in the Hunter catchment as it is mostly outside the Darling Riverine Plains, Cobar Peneplain, MurrayDarling Depression, Riverina and NSW South Western Slopes Bioregions; that portion of the catchment within the Brigalow Belt South bioregion comprises the Tertiary basalts of the Merriwa Plateau, where very few records exist.

Over recent years, fines for the removal of purported individuals of Acacia pendula in the Hunter have been imposed through the NSW Land and Environment Court (e.g. Plath v Hunter Valley Property Management Pty Limited [2010] NSWLEC 264), and have been reported in the media (e.g. McCarthy 2011; Ryan 2011). Additionally, approval conditions for a number of coal mines in the Hunter Valley have requirements for the re-establishment and protection of Acacia pendula to compensate for the removal of this species from mine paths. Typical of these are that "the proponent shall ensure that the offset strategy and/or rehabilitation strategy is focused on the re-establishment of.... Weeping Myall (Acacia pendula)..." from the Mt Arthur consolidation approval in 2010 (BHP Billiton 2010), and "the establishment of a Weeping Myall Management Area within the Project area to promote the recovery of the Weeping Myall (Acacia pendula) in the Hunter Catchment Endangered Population" included in the biodiversity offset strategy for the Bulga Coal optimisation project (Bulga Coal Management Pty Ltd 2013). Based on information available at the time, measures such as these are commensurate with obligations and responsibilities demanded under threatened species legislation. The new evidence discussed in this paper raises the possibility that a change may be required in the management of Acacia pendula in the Hunter; perhaps even recognising the species as an introduced woody weed rather than a species of high conservation status. This is a difficult realisation to make, particularly for a region where Acacia pendula has been a flagship threatened species for at least a decade, and where government grants have been forthcoming for the management of remnant stands of this species and the community which it characterises (e.g. Thompson 2012). Prior to this, however, it is imperative that genetic studies be undertaken to identify the origins of current plants.

There are few precedents in the literature of listed significant plant species being delisted due to misidentification or confusion over origins. Schaefer et al. (2011) report on the single-population endemic Marsilea azorica from the Azores in the northern Atlantic, described in 1983 and listed as critically endangered on the IUCN red list and considered a species of conservation priority in Europe. Following 


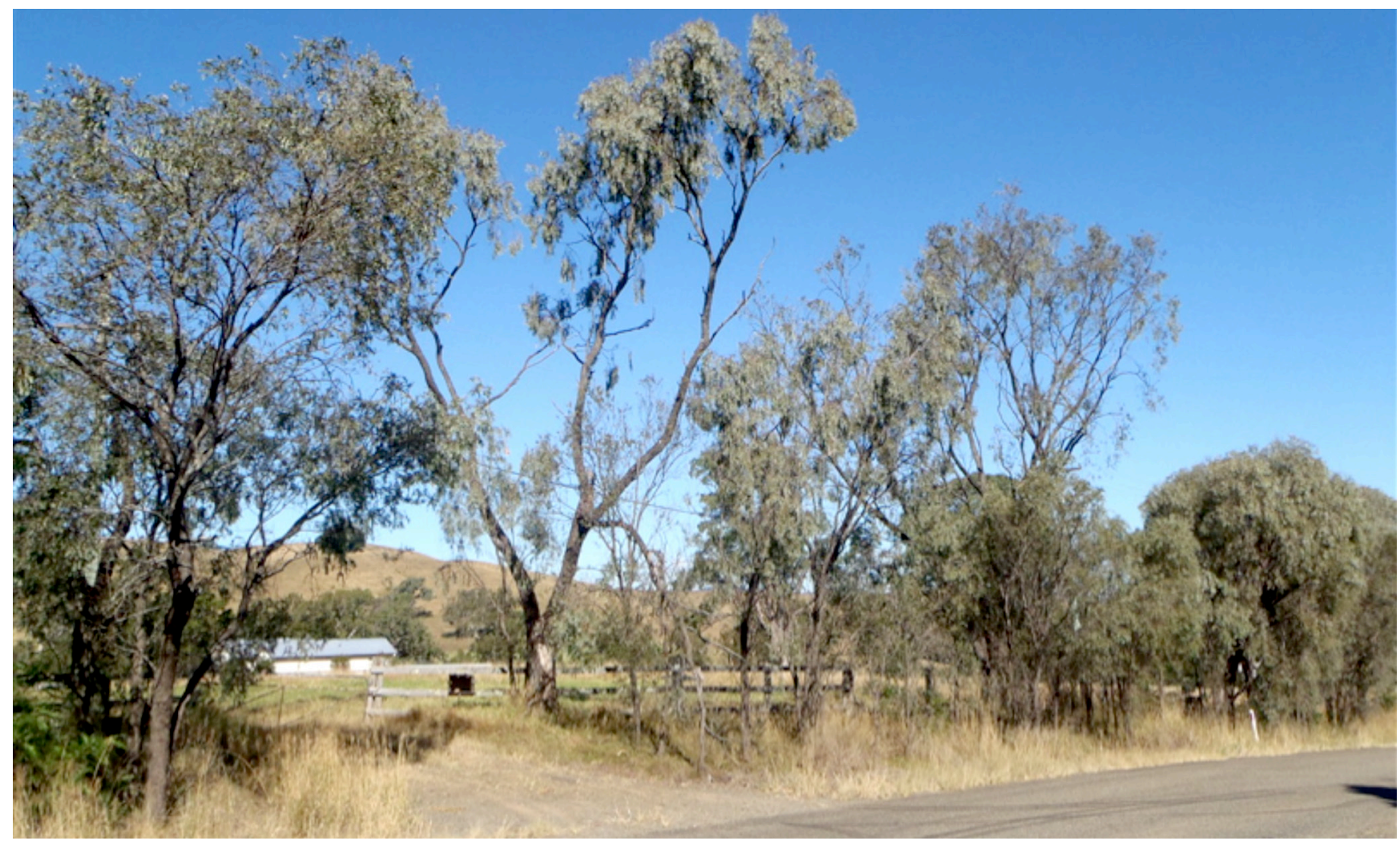

Fig. 5. Acacia pendula naturalising along the road at Bingleburra, between East Gresford and Dungog. Note the original, taller planted trees along the fenceline, and the younger plants recruited probably after seed scarification by roadworks.

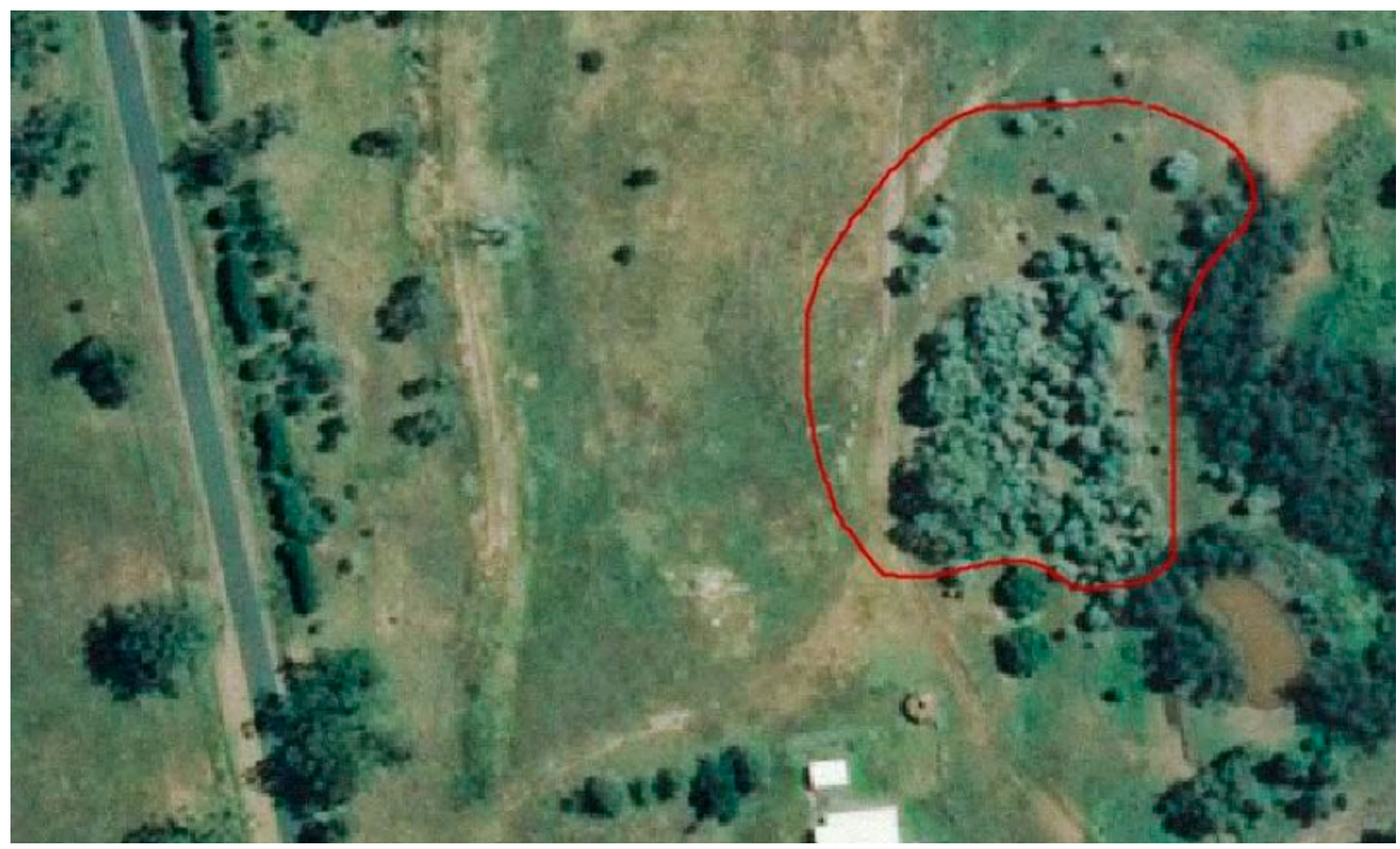

Fig. 6. Aerial view of Acacia pendula naturalising at a property near Muswellbrook. The original, taller planted trees occur on the left hand side of the stand. Scale 1:1000. 
morphological and molecular data analysis, Schaefer et al. (2011) demonstrated that this taxon was alien to the region, conspecific with the Australian Marsilea hirsuta, and consequently recommended removal from all conservation priority lists. In this case, taxonomic confusion led to the application of the highest conservation priority ranking within Macaronesia for a species, despite the relatively late (1983) discovery of the taxon along a roadside within a heavily grazed landscape. In a remarkable parallel with Acacia pendula, Marsilea was not mentioned in any of the plant inventories prepared during the 1800 s, and field-based plant lists failed to record the genus for the first 70 years of the $20^{\text {th }}$ century (Schaefer et al. 2011).

A second example is an aquatic species occurring within the port of Newcastle at the mouth of the Hunter River. In studying the germination characteristics of the New South Wales listed endangered Zannichellia palustris, Greenwood and DuBowy (2005) postulated that this Western European and North American aquatic species may have been introduced to Australia through trans-national shipping, and should be regarded as an exotic, naturalised species rather than one of conservation significance. The few Australian records for a species with high fecundity and abundance in other parts of the world, and the finding by Greenwood and DuBowy (2005) that cool water temperatures and low salinity are required to induce germination, lend support to this hypothesis. At present, however, this species remains listed as endangered in New South Wales. Similarly, while not dealing with threatened species, Mills (2009, 2010) discusses problems in the definition of indigenous species from Norfolk Island, where land management agencies grapple with control of native and introduced taxa.

It may be argued that there is some merit in the protection of Acacia pendula in the Hunter Valley, given the extent to which the species characterises threatened ecological communities in interior parts of Australia; as noted previously, the species is listed as threatened as various entities across three States. But is it possible that protection of Acacia pendula in the Hunter through endangered species legislation may actually be posing a threat to the naturally occurring and endangered grassy woodlands that occupy much of the valley floor remnants? Many stands of Acacia pendula have formed dense thickets of plants as a result of root suckering following the easing of grazing pressure; indeed, new stands are now emerging from subterranean roots in grazing land where stock have been completely removed. It is likely that the 2050 'juvenile' Acacia pendula reported by Bulga Coal Management Pty Ltd (2013) for one site are merely root suckers following stock removal. At Wambo, sampling of all species present in 2007 showed there to be very few shrub and ground-layer species evident, and it was postulated that resource competition induced from dense shading or allelopathy may be the limiting factor (Bell 2007).

How conceivable is it that by protecting Acacia pendula we may be promoting an emerging threat to the endangered forests and woodlands of the Hunter (the State-listed Central Hunter Grey Box - Ironbark Woodland, Central Hunter Ironbark - Spotted Gum - Grey Box Forest, Hunter Valley
Footslopes Slaty Gum Woodland, Hunter Lowlands Redgum Forest, and White Box - Yellow Box - Blakely's Redgum Woodland; and the Commonwealth White Box - Yellow Box - Blakely's Redgum Grassy Woodland and Derived Native Grassland and the nominated Hunter Valley Remnant Open Forests and Woodlands)? Cuneo and Leishman (2013) have recently outlined the threats posed by the invasive African Olive (Olea europea subsp. cuspidata) in the threatened grassy woodlands of the Cumberland Plain in western Sydney. They found that the capacity of this species to form dense stands of shrubs to $10 \mathrm{~m}$ in height, decreasing the diversity of native grassy woodland species, posed a significant threat to Cumberland Plain Woodland. Regenerating stands of Acacia pendula, particularly morphotypes $\mathrm{B}$ and $\mathrm{C}$, appear to be projecting a similar threat onto the threatened grassy woodlands of the Hunter, performing the role of 'ecological engineer' in the terminology of Cuneo \& Leishman (2013) as it alters the structural makeup of the vegetation. Similarly, Radford et al. (2001) noted that Acacia nilotica, originally introduced from Africa as a stock browse and shade species, has now spread to become a serious weed in parts of the Northern Territory. Reid and Murphy (2008) discuss the implications for herbaria when identification of native Acacias is confused with weedy introduced species which may go un-noticed. Further investigations into the population dynamics of Acacia pendula and invasive species research is required to address issues such as these.

\section{There is an urgent need for genetic studies}

There is clearly an urgent need for genetic studies to be undertaken on Hunter Valley plants to validate the concerns raised in this paper. As with investigations into other aridzone Acacias (e.g. Miller et al. 2002; Page et al. 2011; O'Brien et al. 2014) this should aim to clarify origins and define taxonomic limits of Acacia pendula and its close relatives, and should encompass all three Hunter Valley morpho-types recognised here. Some preliminary work on this issue has commenced, and Acacia pendula is now included in the Restore \& Renew NSW research project being co-ordinated by the Royal Botanic Gardens and Domain Trust in Sydney (http://www.rbgsyd.nsw.gov.au/ science/Evolutionary_Ecology_Research/RestoreNSW). Should genetic studies show that parts of the Hunter Valley population of Acacia pendula (e.g. morpho-types B and/or C) are distinct new species, then appropriate conservation measures should be implemented.

\section{Conclusion}

For the long-term protection of threatened ecosystems in the Hunter Valley, there is a need to seriously review the genetic integrity, taxonomic position, conservation status and management of Acacia pendula stands that occur there. Evidence from early explorers, herbarium and database records, and habitat characteristics raise a number of doubts over the validity of currently accepted understandings, and advocate such a review. Until then (and to paraphrase the words of McDougall (2004) when he was debating 
the weedy or threatened status of Ammobium alatum in southeastern Australia), all new populations of Acacia pendula well outside of its historical range (which would include the Hunter Valley) should perhaps be regarded as weedy in whatever situation they occur, irrespective of their determined identities. Such a view is problematic, however, given the current listing of Acacia pendula as a threatened population and a characteristic species in two endangered ecological communities. In the interim, the 'shifting baseline' syndrome discussed by Clavero (2014) is apt to encapsulate the Hunter Acacia pendula population: that which adopts new species into the assumed normal or desirable state of natural systems, compelling societies to monitor, protect and restore them when they become threatened. The practical management implications of such a syndrome are important to understand fully: there may well be other taxa within the Hunter region, or indeed elsewhere in New South Wales, that are currently unnecessarily protected through legislation, channelling limited recovery funding away from more legitimate threatened taxa.

\section{Acknowledgements}

A number of people have assisted greatly over the years with deliberations and discussions on the Hunter population of Acacia pendula. Many thanks to Tricia Hogbin (OEH), Travis Peake (Umwelt), Terry Tame, Barbara Wiecek (National Herbarium of NSW), Maggie Nightingale and Brendan Lepschi (DSEWPAC), Tom Darragh (Museum of Victoria), Martin Fallding (Land \& Environment Planning) and the Singleton Historical Society. Additional records of Acacia pendula were provided by colleagues Alex Cockerill and Tas Willis. Thanks also to Tony Orchard for searching and extracting unpublished information from relevant parts of the writings of Allan Cunningham, and for leading us to scanned collections of Acacia pendula at Kew. Sections of the work presented here originated through a DSEWPAC contract to SB for a review of the Weeping Myall-CoobahScrub Wilga Shrubland of the Hunter Valley threatened ecological community. Martin Fallding, Bob Makinson, Doug Benson, and an anonymous reviewer provided critical comments on an earlier version of this paper.

\section{References}

Anon (1895) Notice in Singleton Argus, Wednesday $30^{\text {th }}$ October 1895 , p. 2.

Anon (1947) Advertisement in Singleton Argus, Monday $4^{\text {th }}$ August 1947, p. 3.

Auld, T.D. (1986) Dormancy and viability in Acacia suaveolens (Sm.) Willd. Australian Journal of Botany 34: 463-472.

Aurousseau, M. (1968) The Letters of F.W. Ludwig Leichhardt. Volume 2. The Hakluyt Society. Cambridge University Press, London. Online at http://books.google.com.au/books?id=SMrLqILKG0C\&printsec $=$ frontcover\&source=gbs_ge_summary $\mathrm{r} \& \mathrm{cad}=0 \# \mathrm{v}=$ onepage $\& \mathrm{q}=$ patrick $\& \mathrm{f}=$ false

Aveyard, J.M. (1968) The effect of seven pre-growing seed treatments on total germination and germination rate of six Acacia species. Journal of the Soil Conservation Service NSW 24: 43-54.
Bell, S.A.J. (2006) An investigation into Acacia pendula on land owned by Wambo Coal Company, Warkworth. Unpublished Report to HLA Envirosciences Pty Ltd. Eastcoast Flora Survey. July 2006.

Bell, S.A.J. (2007) Acacia pendula in the Hunter Valley: Update of investigations. Unpublished Report to HLA Envirosciences Pty Ltd \& Wambo Coal Mine. Eastcoast Flora Survey. June 2007.

Bell, S.A.J. (2012) Update of Listing Advice and Fact Sheet for Weeping Myall - Coobah - Scrub Wilga Woodland/Low Forest of the Hunter Valley. Unpublished Report to the Commonwealth Department of Sustainability, Environment, Water, Populations and Communities. Eastcoast Flora Survey, June 2012.

Bell, S., Peake, T., \& Driscoll, C. (2007) Dealing with taxonomic uncertainty in Weeping Myall Acacia pendula from the Hunter catchment, New South Wales. Australasian Plant Conservation 16(1): 14-15.

Benson, J.S. (2006) New South Wales Vegetation Classification and Assessment: Introduction - the classification, database, assessment of protected areas and threat status of plant communities. Cunninghamia 9(3): 331-382.

Benson, J.S. \& Redpath, P.A. (1997) The nature of pre-European native vegetation in south-eastern Australia: a critique of Ryan, D.G., Ryan, J.R. \& Starr, B.J. (1995) The Australian Landscape - Observations of Explorers and Early Settlers. Cunninghamia 5 (2): 285-328.

Benson, J.S., Richards, P.G., Waller, S., \& Allen, C.B. (2010) New South Wales Vegetation classification and Assessment: Part 3 Plant communities of the NSW Brigalow Belt South, Nandewar and west New England Bioregions and update of NSW Western Plains and South-western Slopes plant communities, Version 3 of the NSWVCA database. Cunninghamia 11(4): 457-579.

BHP Billiton (2010) Mt Arthur Coal Mine - Open Cut Consolidation Project, Project Approval Conditions of Consent. Online resource: http://www.bhpbilliton.com/home/aboutus/regulatory/Documents/ mac ProjectApprovalSigned.pdf [Accessed 15 July 2013].

Boland, D.J., Brooker, M.I.H., Chippendale, G.M., Hall. N., Hyland, B.P.M., Johnston, R.D., Kleinig, D.A., McDonald, M.W., \& Turner, J.D. (2006) Forest Trees of Australia. Fifth Edition. CSIRO, Collingwood.

Breton, W.H. (1833) Excursions in New South Wales, Western Australia and Van Diemen's Land, during the years 1830, 1831, 1832 and 1833. London: Richard Bentley.

Bulga Coal Management Pty Limited (2013) Ecological Impact Assessment: Bulga Optimisation Project. Volume 4, Appendix 9. Bulga Coal Management Pty Limited, April 2013.

Bureau of Meteorlogy (2013) Rainfall statistics. Online at: http:// www.bom.gov.au/

Butler, DW (2007) Recovery plan for the "Brigalow (Acacia harpophylla dominant and co-dominant" endangered ecological community (draft of 1 May 2007). Report to the Department of the Environment and Water Resources, Canberra. Queensland National Parks and Wildlife Service, Brisbane.

Cameron, L. M. (1935) The regional distribution of vegetation in New South Wales. Australian Geographer 2(5): 18-32.

Clavero, M. (2014) Shifting baselines and the conservation of nonnative species. Conservation Biology doi: 10.1111/cobi.12266 (early view online)

Copeland L.M. \& Kodela P.G. (2012) Acacia atrox subsp. planiticola (Fabaceae: Mimosoideae), a new threatened subspecies from the North Western Plains of New South Wales, Australia. Telopea 14: 63-68.

Costello, D.A., Lunt, I.D., \& Williams, J.E. (2000) Effects of invasion by the indigenous shrub Acacia sophorae on plant composition of coastal grasslands in south-eastern Australia. Biological Conservation 96: 113-121.

Cowan, R.S. (2001) Acacia pendula. Flora of Australia IIB: 110-111. 
Cowan, R.S. \& Maslin, B.R. (2001) Acacia omalophylla. Flora of Australia IIB: 111-112.

Cromer, E.L. (2007) Seed germination and research records from Alcoa's Marrinup Nursery. Alcoa World Alumina Australia. Research Report No. 27.

Cunningham, A. (1825) Journal of a route from Bathurst to Liverpool Plains, in New South Wales. In Geographical Memoirs on New South Wales. Ed. by Barron Field. London.

Cunningham, A. (1828) The late tour of A. Cunningham Esq.. Australian Quarterly Journal 1: 65-85.

Cunningham, A. (1832a) Journal of Allan Cunningham's Excursions, 1822 - 1832. [Copy held in Mitchell Library, Sydney. Reference A1746-1].

Cunningham, A. (1832b) Brief view of the progress of interior discovery in New South Wales. Proceedings of the Royal Geographical Society of London 2: 99-132.

Cunningham, G.M., Mulham, W.E., Milthorpe, P.L., \& Leigh, J.H. (2011) Plants of Western New South Wales. CSIRO Publishing, Collingwood.

Cuneo, P. \& Leishman, M.R. (2013) Ecological impacts of invasive African olive (Olea europea ssp. cuspidata) in Cumberland Plain Woodland, Sydney, Australia. Austral Ecology 38(1): 103-110.

Danthu, P., Ickowicz, A., Friot, D., Manga, D., \& Sarr, A. (1996) Effect of the passage through the digestive tracts of domestic ruminants on the germination of woody leguminous tree seeds in the semi-arid tropics. Revue dElevage et de Medecine Veterinaire des Pays Tropicaux, 49(3): 235-242.

Darragh, T. \& Fensham, R. (2013) The Leichhardt diaries. Early travels in Australia during 1842-1844. Memoirs of the Queensland Museum - Culture 7(1): 1-540.

Don, G. (1832) A General History of Dichlamydeous Plants 2, 404.

Dumaresq, W.J. (1827) Rambles in New South Wales. P 247. Extract from the New Monthly Magazine and Literary Journal (1828). London, 1828. Attributed to W.J. Dumaresq. A series of letters originally published in the "Australian", between 1826 and 1827 and signed: X.Y.Z

Dunne, A. (2012) From Brook to Broke: A History of Broke Fordwich. Xstrata Coal, Bulga Complex \& Hunter History Consultants Pty Ltd.

Dynes, R.A. \& Schlink, A.C. (2002) Livestock potential of Australian species of Acacia. Conservation Science of Western Australia 4(3): 117-124.

Eichhorn, M.P., Ratliffe, L.C., \& Pollard, K.M. (2011) Attraction of ants by an invasive Acacia. Insect Conservation and Diversity 4: 235-238.

Ellis, I. (no date) Jerrys Plains: The First 100 Years. The Author.

Emms, J., Virtue, J.G., Preston, C., \& Bellotti, W.D. (2005) Legumes in temperate Australia: A survey of naturalisation and impact on natural ecosystems. Biological Conservation 125: 323-333.

Eyre, E.J. (1845) Journals of Expeditions of Discovery into Central Australia and Overland from Adelaide to King George's Sound in the 1840-41: Sent by the Colonists of South Australia with the Sanction and Support of the Government. Includes an Account of the Manners and Customs of the Aborigines and the State of their Relations with Europeans. Volumes $1 \&$ 2. T. and W. Boone, London. Online at http://gutenberg.net.au/explorers-journals.html

Fallding, M. \& Benson, D. (2013) Adventures, hardships and a scientific legacy: Ludwig Leichhardt's 1843 journey to Mt Royal in the Hunter Valley, NSW. Cunninghamia 13: 305-330.

Fensham, R.J. (2013) For the sake of science: Ludwig Leichhardt as botanist and ecologist. Memoirs of the Queensland Museum - Culture 7(2): 599-620.

Fensham, R.J., \& Fairfax, R.J. (1997). The use of the land survey record to reconstruct pre-European vegetation patterns in the Darling Downs, Queensland, Australia. Journal of Biogeography 24: 827-836.
Fensham, R.J., Bean, A.R., Dowe, J.L., \& Dunlop, C.R. (2006) This disastrous event staggered me: Reconstructing the botany of Ludwig Leichhardt on the expedition from Moreton Bay to Port Essington, 1844-45. Cunninghamia 9(4): 451-506.

Fox, J.E.D. (1987) Potential of Australian Acacias from arid and semi-arid zones. Pp. 17-28 IN Australian Acacias in Developing Countries. ACIAR Proceedings No. 16. Ed by J.W. Turnbull. Australian Centre for International Agricultural Research, Canberra.

Frawley, J. (2010) Joseph Maiden and the national and transnational circulation of Wattle Acacia spp. Historical Records of Australian Science 21: 35-54.

Froggatt, W.W. (1923) Forest Insects of Australia. Forestry Commission of New South Wales.

Gallant, J.C., Dowling, T.I., Read, A.M., Wilson, N., Tickle, P., Inskeep, C. (2011) 1 second SRTM Derived Digital Elevation Models User Guide.

Gardener, C.J., McIvor, J.G., \& Jansen, A. (1993) Passage of legume and grass seeds through the digestive tract of cattle and their survival in faeces. Journal of Applied Ecology 30: 63-74.

Ghassali F., Salkini A. K., Petersen S. L., Niane A. A., \& Louhaichi M. (2012) Germination dynamics of Acacia species under different seed treatments. Range Management and Agroforestry 33(1): 37-42.

Giles, E. (no date) Australia Twice Traversed: The Romance Of Exploration, Being A Narrative Compiled From The Journals Of Five Exploring Expeditions Into And Through Central South Australia, And Western Australia, From 1872 To 1876. Fellow, And Gold Medallist, Of The Royal Geographical Society Of London. Online at http://gutenberg.net.au/explorers-journals.html

Goodchild, A.V., \& McMeniman, N.P. (1987) Nutritional value of Acacia foliage and pods for animal feeding. Pp. 101-106 IN Australian Acacias in Developing Countries. ACIAR Proceedings No. 16. Ed by J.W. Turnbull. Australian Centre for International Agricultural Research, Canberra.

Greenwood, M.E. \& DuBowy, P.J. (2005) Germination characteristics of Zannichellia palustris from New South Wales. Aquatic Botany 82: 1-11.

Griffiths, J. (2012) Industry \& Perseverance: A History of David Brown (1750-1836) and Family. Searcher, Queanbeyan. Online at http://www.davidbrown1801nsw.info

Haarmeyer, D.H., Bösing, B.M., Schmiedel, U., \& Dengler, J., (2010) The role of domestic herbivores in endozoochorous plant dispersal in the arid Knersvlakte, South Africa. South African Journal of Botany 76, 359-364.

Hameed, M., Khan, R., Ashraf, M., Nawaz, T., Sajid Aqeel Ahmad, M., \& Mubarik, S. (2011). Influence of plantation type on ground flora composition and diversity in Gatwala Artificial Forest Plantation. Pakistan Journal of Botany 43(4), 1867-1872.

Harris, M.R., Lamb, D. \& Erskine, P.D. (2003). An investigation into the possible inhibitory effects of white cypress pine (Callitris glaucophylla) litter on the germination and growth of associated ground cover species. Australian Journal of Botany 51(1), 93-102.

Hosking, J.R., Conn, B.J., \& Lepschi, B.J. (2003) Plant species first recognised as naturalised for New South Wales over the period 2000-2001. Cunninghamia 8(2): 175-187.

Hosking, J.R., Conn, B.J., Lepschi, B.J., \& Barker, C.H. (2007) Plant species first recognised as naturalised for New South Wales in 2002 and 2003, with additional comments on species recognised as naturalised in 2000-2001. Cunninghamia 10(1): 139-166.

Hosking, J.R., Conn, B.J., Lepschi, B.J. \& Barker, C.H. (2011) Plant species first recognised as naturalised or naturalising for New South Wales in 2004 and 2005. Cunninghamia 12 (1): 85-114.

Hunter, C. (2010) People Property Power: Plashett Jerry's Plains. Anglo American Metallurgical Coal Pty Ltd, Brisbane.

Jeddi, K. \& Chaieb, M. (2012) Restoring degraded arid Mediterranean areas with exotic tree species: influence of an age sequence of Acacia salicina on soil and vegetation dynamics. Flora 207: 693-700. 
Jervis, J. (1953a) The Hunter Valley: A century of its history. Part 1. Royal Australian Historical Society Journal and Proceedings 39(3): 97-150.

Jervis, J. (1953b) The Hunter Valley: A century of its history. Part 2. Royal Australian Historical Society Journal and Proceedings 39(4): 191-202.

Johnson, R.W. \& Burrows, W.H. (1994) Acacia open-forests, woodlands and shrublands. Chapter 9 Pp 257-290 IN Australian Vegetation, edited by R.H. Groves. Cambridge University Press, Second Edition.

Keith, D.A. (2004) Ocean Shores to Desert Dunes: The Native Vegetation of New South Wales and the ACT. Department of Environment and Conservation: Hurstville.

Kodela, P.G. (2001) Acacia atrox (Fabaceae: Mimosoideae), a new rare species from the North Western Slopes, New South Wales. Telopea 9(2): 415-419.

Kodela, P. \& Harden, G. (2002) Acacia. In Flora of New South Wales, Volume 2. NSW University Press, Kensington.

Landsborough, W. (1862) Journal of Landsborough's Expedition from Carpentaria, in Search of Burke and Wills. With a map showing his route. F.F. Bailliere, London. Online at http://gutenberg.net.au/ explorers-journals.html

Lang, R.D. (2008) Defining the original extent and floristic composition of the naturally-treeless grasslands of the Liverpool Plains, North Western Slopes, New South Wales. Cunninghamia 10(3): 407-421.

Larsen, E. (1964) Germination response of Acacia seeds to boiling. Australian Forestry Research 1: 51-53.

Lee, I. (1925) Early Explorers in Australia: From the log books and journals with maps and illustrations. Methuen \& Co. Ltd. London. Online at http://www.artuccino.com/Allan_ Cunningham/Ida_Lee/ Index.html]

Leichhardt, L. (1847) Journal Of An Overland Expedition In Australia: From Moreton Bay To Port Essington, A Distance Of Upwards Of 3000 Miles, During The Years 1844-1845. London. Online at http://gutenberg.net.au/explorers-journals.html

Lorenzo, P., Pazos-Malvido, E., Reigosa, M.J., \& Gonzalez, L. (2010) Differential responses to allelopathic compounds released by the invasive Acacia dealbata Link (Mimosaceae) indicate stimulation of its own seed. Australian Journal of Botany 58(7): 546-553.

Lorenzo, P., Pazos-Malvido, E., Rubido-Bara, M., Reigosa, M.J. \& Gonzalez, L. (2012) Invasion by the leguminous tree Acacia dealbata (Mimosaceae) reduces the native understory plant species in different communities. Australian Journal of Botany 60(8): 669-675.

Lucas, C. (2013) Hunter Estates: A Comparative Heritage Study of pre 1850s Homestead Complexes in the Hunter Region. Volume 1: Historical Context and Survey of Sites. State of NSW and the NSW Office of Environment and Heritage. Online at http://www. environment.nsw.gov.au/resources/heritagebranch/heritage/ media/13235huntesvol1.pdf

Macqueen, A. (2004) Somewhat Perilous: the journeys of Singleton, Parr, Howe, Myles \& Blaxland in the Northern Blue Mountains. Andy Macqueen: Wentworth Falls.

Maiden, J.H. (1889) The Useful Native Plants of Australia (including Tasmania). Turner and Henderson: Sydney. Online at http://www.archive.org/stream/usefulnativeplan1889maid\#p age/300/mode/2up

Malcolm, P. (2012) Acacia pendula. In: IUCN 2012. IUCN Red List of Threatened Species. Version 2012.2. <www.iucnredlist. org>. Downloaded on 14 May 2013.

Maslin, B.R. (1994) Notes on Acacia adunca and A. linearifolia, and the description of a new subspecies of A. juncifolia (Leguminosae: Mimosoideae) from eastern Australia. Telopea 6(1): 46-47.
Maslin, B.R., \& McDonald, M.W. (2004) AcaciaSearch-evaluation of Acacia as a woody crop option for southern Australia. Rural Industries Research Development Corporation Publication No. 03/017, Canberra.

Maslin, B.R., Orchard, A.E., \& West, J.G. (2003) Nomenclatural and classification history of Acacia (Leguminosae: Mimosoideae), and the implications of generic subdivision. Unpublished paper available online at http://www.worldwidewattle.com/ infogallery/taxonomy/nomen-class.pdf

McCarthy, J. (2011) Spot the difference. Newcastle Herald March 5, 2011.

McDougall, K. (2004) Winged Everlasting Ammobium alatum threatened species, weed or itinerant? The Victorian Naturalist 121(6): 284-288.

McDougall, K.L.(2008) Evidence for the natural occurrence of treeless grasslands in the Riverina region of south-eastern Australia. Australian Journal of Botany 56(6): 461-468.

McMinn, W.G. (1970a) The opening of the Hunter Valley. Hunter Natural History 2(2): 7-11.

McMinn, W.G. (1970b) Allan Cunningham: Botanist and Explorer. Melbourne University Press.

Millar, M.A. \& Byrne, M. (2012) Biogeographic origins and reproductive mode of naturalised populations of Acacia saligna. Australian Journal of Botany 60(5): 383-395.

Miller, M.F. \& Coe, M. (1993) Is it advantageous for Acacia seeds to be eaten by ungulates? Oikos 66(2): 364-368.

Miller, J.T., Andrew, R.A., \& Maslin, B.R. (2002) Towards an understanding of variation in the Mulga complex (Acacia aneura and relatives). Conservation Science of Western Australia 4(3): 19-35.

Miller, M.F. (1993) Is it advantageous for Acacia seeds to be eaten by ungulates? Oikos 66(2): 364-368.

Mills, K. (2009) Was Phormium tenax introduced to Norfolk Island by the Polynesians? Cunninghamia 11(2): 171-175.

Mills, K. (2010) Defining indigenous plants: some problematic species from Norfolk Island. Cunninghamia 11(4): 409-414.

Mitchell, T.L. (1838) Three Expeditions Into The Interior Of Eastern Australia; With Descriptions Of The Recently Explored Region Of Australia Felix, And Of The Present Colony Of New South Wales. Second Edition, Carefully Revised. In Two Volumes. London: T. and W. Boone, New Bond Street. Online at http://gutenberg.net.au/explorers-journals.html

Mitchell, T.L. (1848) Journal of an Expedition into the Interior of Tropical Australia in Search of a Route from Sydney to the Gulf of Carpentaria. Online at http://gutenberg.net.au/explorers-journals.html

Morgan, A., Carthew, S.M. \& Sedgley, M. (2002) Breeding system, reproductive efficiency and weed potential of A. baileyana. Australian Journal of Botany 50(3): 357-364.

Morgan, J.W., Kviecinskas, P.A., \& Maron, M. (2013) Effect of proximity of buloak (Allocasuarina luehmannii) trees on buloke early sapling survival in a semiarid environment. Australian Journal of Botany 61(4): 302-308.

Moxham, C., Sinclair, S., Walker, G., \& Douglas, I. (2009) The vegetation of the Nepean Peninsula, Victoria - an historical perspective. Cunninghamia 11(1): 27-48.

Murray, M. \& Bell, S.A.J. (2010) Mangoola Coal Project Ecological Monitoring Annual Report 2009. Unpublished Report to Mangoola Coal. Forest Fauna Surveys P/L \& Eastcoast Flora Survey.

NSW Department of Primary Industries (2006) Geological Survey of New South Wales. NSW 1:100 000 Rectified Geology Maps and 1:100 000 Vector Data.

NSW National Parks and Wildlife Service (1999) Forest ecosystem classification and mapping for the Hunter sub-region in the Lower North East Comprehensive Regional Assessment. A project undertaken for the Joint Commonwealth-NSW Regional Forest Agreement Steering Committee as part of the NSW Comprehensive Regional Assessments. Project No. NL 10E/H \& NL 02/ EH. CRA Unit, Sydney Zone NPWS. March 1999. 
NSW National Parks and Wildlife Service (2000). Vegetation survey, classification and mapping: Lower Hunter and Central Coast region. A project undertaken for the Lower Hunter and Central Coast Regional Environmental Management Strategy by CRA Unit, Sydney Zone, NPWS. April 2000

NSW Office of Environment and Heritage (2013) Australian Soil Classification (ASC) Soil Type of NSW. Website: http://mapdata.environment.nsw.gov.au/geonetwork/ srv/en/main.home

NSW Scientific Committee (2006) Final Determination to list Hunter Valley Weeping Myall Woodland of the Sydney Basin Bioregion as an endangered ecological community. NSW Scientific Committee.

O’Brien, E.K., Denham, A.J., \& Ayre, D.J. (2014) Patterns of genotypic diversity suggest a long history of clonality and population isolation in the Australian arid zone shrub Acacia carneorum. Plant Ecology 215: 55-71.

O'Rourke, M. (2009) Passages To The North-West Plains: The Colonial Discovery And Occupation Of East-Central New South Wales, 1817-26. Oxley, Howe, Lawson And Cunningham. Mudgee, Merriwa, And Muswellbrook. Incorporating An Extended Discussion Of The Armed Conflict Between Aborigines, Settlers And Police In The Hunter Valley, 1825-26. Canberra, Australia. December 2009.

Oxley, J. (1820) Journals of Two Expeditions into the Interior of NSW in 1817 and 1818. London: John Murray. Online at http:// setis.library.usyd.edu.au/ozlit/pdf/p00066.pdf.

Page, G.F.M., Cullen, L.E., van Leeuwen, S., \& Grierson, P.F. (2011) Inter- and intra-specific variation in phyllode size and growth form among closely related Mimosaceae Acacia species across a semiarid landscape gradient. Australian Journal of Botany 59(5): 426-439.

Paynter, Q., Csurhes, S. M., Heard, T.A., Ireson, J., Julien, M.H., Lloyd, J., Lonsdale, W.M., Palmer, W.A., Sheppard, A.W. \& van Klinken, R.D. (2003) Worth the risk? Introduction of legumes can cause more harm than good: an Australian perspective. Australian Systematic Botany 16(1): 81-88.

Peake, T.C. (2006) The Vegetation of the Central Hunter Valley, New South Wales. A report on the findings of the Hunter Re mnant Vegetation Project. Hunter-Central Rivers Catchment Management Authority, Paterson.

Perry, T.M. (1955) The spread of rural settlement in New South Wales, 1788-1826. Historical Studies: Australia and New Zealand 6(24): 377-395.

Popinjay Publications (1990) A Visit to Wollombi and Cumnaroy (Jerry's Plains) performed in August 1827: with certain reflections arising from the journey Narrated in eight letters published in the Australian 24 August - 17 October 1827.

Porteners, M.J. (1993) The Natural Vegetation of the Hay Plain: Booligal-Hay and Deniliquin-Bendigo 1:250,000 Maps. Cunninghamia Vol. 3(1): 1-122.

Radford, I.J., Nicholas, D.M., Brown, J.R. \& Kriticos, D.J. (2001) Paddock-scale patterns of seed production and dispersal in the invasive shrub Acacia nilotica (Mimosaceae) in northern Australian rangelands. Austral Ecology 26(4): 338-348.

Randall, R.P. (2007) The introduced flora of Australia and its weed status. CRC for Australian Weed Management, Department of Agriculture and Food, Western Australia.

Razanamandranto, S. (2004) Effects of gut treatment on recovery and germinability of bovine and ovine ingested seeds of four woody species from the Sudanian savanna in West Africa. Flora Morphology Distribution Functional Ecology of Plants 199(5): 389-397.

Reid, JC \& Murphy, DJ. (2008) Some case studies of Acacia as weeds and implications for herbaria. Muelleria 26(1): 57-66

Rocha, C.F.D. \& Bergallo, H.G. (2012) When invasive exotic populations are threatened with extinction. Biodiversity and Conservation 21(14): 3729-3730.
Ryan, S. (2011) Big cost in court for plant slashing. Newcastle Herald January 6, 2011.

Schaefer, H., Carine, M.A., \& Rumsey, F.J. (2011) From European priority species to invasive weed: Marsilea azorica (Marsileaceae) is a misidentified alien. Systematic Botany 36(4): 845-853.

Schuch, U.K. \& Norem, M. (2004) Growth of legume tree species growing in the Southwestern United States. Part of the University of Arizona College of Agriculture 2004 Turfgrass and Ornamental Research Report (http://cals.arizona.edu/pubs/ crops/az1359)

Shayo, C.M. \& Uden, P. (1998) Recovery of seed of four African browse shrubs ingested by cattle, sheep and goats and the effect of ingestion, hot water and acid treatment on the viability of the seeds. Tropical Grasslands 32: 195-200.

Sivertsen, D., Roff, A., Somerville, M., Thonell, J., \& Denholme, B. (2012) Hunter Native Vegetation Mapping. Geodatabase Guide (Version 4). Internal Report for the Office of Environment and Heritage, Department of Premier and Cabinet, Sydney, Australia.

Smiles, B., Merchant, C., \& Proft, K. (2011) The NSW travelling stock routes and reserves network: Heritage, habitat, livelihood. National Parks Association of NSW, June 2011.

Somerville, M. (2010) Hunter, Central \& Lower North Coast Vegetation Classification \& Mapping Project Volume 2: Vegetation Community Profiles. Report prepared by HCCREMS/ Hunter Councils Environment Division for Hunter-Central Rivers Catchment Management Authority, Tocal, NSW.

Stanley, T.D. \& Ross, E.M. (1995) Flora of South Eastern Queensland. Volume 2. Queensland Department of Primary Industries: Brisbane.

Story, R. (1963a) Vegetation of the Hunter Valley. IN CSIRO Australian Land Research Series No. 8. CSIRO.

Story, R. (1963b) Supplementary notes on the vegetation of the Hunter Valley land systems. CSIRO Australian Division of Land Research Reg. Surv. Tech. Memo 63/1.

Story, R. (1967) Pasture patterns and associated soil water in partially cleared woodland. Australian Journal of Botany 15: 175-187.

Sturt, C. (1833) Two Expeditions Into The Interior Of Southern Australia During The Years 1828, 1829, 1830, 1831 with Observations On The Soil, Climate And General Resources Of The Colony Of New South Wales. Online at http://gutenberg.net. au/explorers-journals.html

Tame, T. (1984) Vegetation of the Hunter Valley. Volumes $1 \& 2$. Unpublished.

Tame, T. (1992) Acacias of Southeast Australia. Kangaroo Press, Kenthurst.

Thompson, F. (2012) Weeping myalls owe life to old cemetery. Newcastle Herald May 24, 2012.

Umwelt (Australia) Pty Limited (2006a) Status of the Endangered Ecological Community, Hunter Valley Weeping Myall Woodland. Prepared by Umwelt (Australia) Pty Limited for the Department of Environment and Conservation (NSW).

Umwelt (Australia) Pty Limited (2006b) The vegetation of Jerry's Plains cemetery: A survey for weed management purposes. Unpublished Report to Department of Environment and Conservation, December 2006.

Venier, P., Carrizo Garcia, C., Cabido, M., \& Funes, G. (2012) Survival and germination of three hard-seeded Acacia species after simulated cattle ingestion: The importance of the seed coat structure. South African Journal of Botany 79: 19-24.

Venn, D.R. (2004) Action Statement No. 86: Flora and Fauna guarantee Act 1988: Weeping Myall, Acacia pendula. VIC Department of Sustainability and Environment, Melbourne.

VIC Department of Sustainability and Environment (2009) Advisory list of environmental weeds of the Inland Plains bioregions of Victoria. Department of Sustainability and Environment.

Manuscript accepted 25 November 2014 